
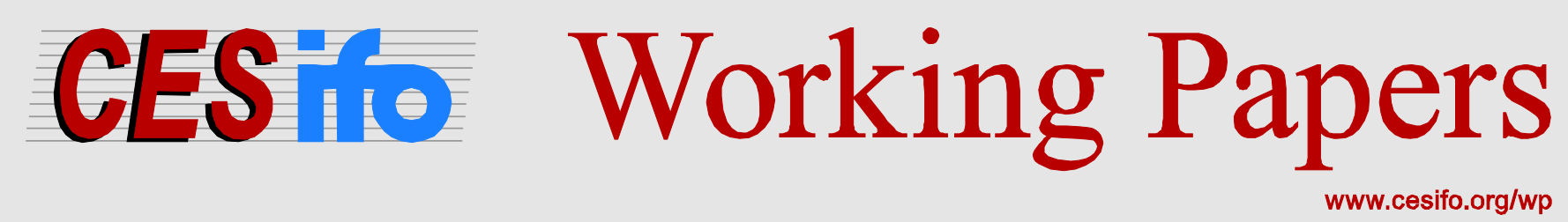

\title{
The Effect of Policy Uncertainty on Investment Plans: Evidence from the Unexpected Acceptance of a Far-Reaching Referendum in Switzerland
}

\author{
Klaus Abberger \\ Andreas Dibiasi \\ Michael Siegenthaler \\ Jan-Egbert Sturm
}

\author{
CESIFO WORKING PAPER NO. 5887 \\ CATEGORY 6: Fiscal POLICY, MACROECONOMICS AND GROWTH \\ MAY 2016 \\ An electronic version of the paper may be downloaded \\ - from the SSRN website: \\ - from the RePEc website: \\ WWW.SSRN.cOm \\ - from the CESifo website: \\ www.RePEc.org \\ www.CESifo-group.org/wp
}




\title{
The Effect of Policy Uncertainty on Investment Plans: Evidence from the Unexpected Acceptance of a Far-Reaching Referendum in Switzerland
}

\begin{abstract}
Does increased policy uncertainty dampen investment plans of firms? We provide direct evidence on this question by examining the effects of an unexpectedly accepted and farreaching referendum in Switzerland in February 2014. The vote has put several economically relevant agreements between Switzerland and its main trading partner, the European Union, at stake. Using firm-level survey data levied before and after the vote, we examine whether firms that reported to be affected by the induced policy uncertainty have revised their investment plans differently from those that did not perceive an increase in uncertainty. We find strong evidence that an increase in policy uncertainty does lead firms to reduce their investment plans. As theoretically expected, these effects are concentrated among those firms that view their investments as largely irreversible. Moreover, the uncertainty shock mainly dampened firms' plans to extend their production capacities, while other types of investment such as replacement investment were not affected.
\end{abstract}

JEL-Codes: D810, D840, E220.

Keywords: investment, uncertainty, irreversibility, business survey.

Klaus Abberger

KOF Swiss Economic Institute

ETH Zurich / Switzerland

abberger@kof.ethz.ch

Michael Siegenthaler

KOF Swiss Economic Institute

ETH Zurich / Switzerland

siegenthaler@kof.ethz.ch
Andreas Dibiasi

KOF Swiss Economic Institute

ETH Zurich / Switzerland

dibiasi@kof.ethz.ch

Jan-Egbert Sturm

KOF Swiss Economic Institute

ETH Zurich / Switzerland

sturm@kof.ethz.ch

This version: May 2016 


\section{Introduction}

A substantial theoretical and empirical literature suggests that uncertainty affects investment decisions of firms. According to Bernanke (1983) and others, firms may, when facing increased uncertainty, prefer to wait-and-see rather than to engage in partially irreversible investment activities which with hindsight might turn out to have been wrong. Yet, uncertainty is an ambiguous concept and remains difficult to capture empirically. The most important challenge is to uncover the causal relationship between uncertainty and investment. The reason is that most macro variables move together over the business cycle. Does uncertainty cause a fall in investment, does a fall in investment cause uncertainty, or does something else drive both? To identify the causal impact of uncertainty on output and investment, recent papers started studying situations in which there is an exogenous shock in uncertainty. For instance, Julio and Yook (2012) use electoral cycles to measure policy uncertainty and Baker and Bloom (2013) propose natural disasters, terrorist events and policy shocks. This approach has the additional advantage that it helps to understand how different forms of uncertainty affect the behaviour of firms - a question that is often of prime interest in itself.

Like Julio and Yook (2012), we focus in our work on the effects of policy uncertainty on investment. This is in our view a particularly interesting source of uncertainty as policy makers often can directly affect it. However, except for (pre-determined) elections, it is in general quite rare to observe truly exogenous policy changes. This paper analyses exactly such a rare event. It studies how the surprising acceptance of a far-reaching popular initiative in Switzerland on February $9^{\text {th }}, 2014$ has affected firms' investment plans. A small majority of the population (of $50.3 \%$ ) voted in favour of the so-called Mass Immigration Initiative (MII). This initiative wants to add an amendment to the Swiss constitution that reintroduces annual quotas on total gross immigration into Switzerland. The outcome of the vote came as a big surprise. All prior opinion polls indicated that the initiative would be rejected, and almost all important political players, including the government, had decisively lobbied against it.

The unexpected result of the vote represented a substantial policy uncertainty shock for Switzerland's firms. Not only is the referendum vaguely formulated, it was also unclear how, or if at all, any new regulations would be implemented after the vote. The reason is that the vote questions the access of Swiss firms to the European labour market and it puts seven economically relevant agreements for the country with its main trading partner, the European Union (EU), at stake. It thereby questions the most important cornerstone of Swiss EU policy: 
the so-called "bilateral way". ${ }^{1}$ After the vote, it was entirely uncertain whether Switzerland could implement new regulations in a way that would be compliant with the bilateral agreements. At the same time, the policy uncertainty created by the vote is temporary: The new constitutional text states that the new amendment to the constitution must be in place early 2017 , i.e. within three years after the referendum.

The initiative thus provides a unique setting in which an unexpected policy shock led to a substantial temporary increase in uncertainty. We examine whether Swiss firms that selfreported an increase in uncertainty because of the policy shock revised their investment plans differently from those that did not experience such a change in perceived uncertainty levels. The data for the analysis stem from several waves of the so-called KOF Investment Survey, a biannual business survey in Switzerland. The survey collects detailed information on investment activities of firms in the recent past and near future. A special section of questions to study the effects of the MII vote extended the first wave of the survey in 2014 and asked firms whether the referendum affected their perceived level of uncertainty. Every seventh firm reported an increase in uncertainty regarding their investment plans triggered by the MII vote.

Besides being able to use what arguably is a natural experiment, this survey allows us to contribute to the literature on the measurement of uncertainty. The most prominent ways of measuring uncertainty include capturing sentiment in newspapers, dispersion of professional forecasters, dispersion of aggregate firm assessment in survey data and volatility measures in equity and bond markets. Our approach to measure uncertainty is more direct and simple. We have asked firms whether the unexpected outcome of the policy vote affected their expected demand and the uncertainty surrounding future investment activities. This simple measure allows us to identify firms whose investment certainty changed as a consequence of the initiative, thus allowing a direct evaluation of the revisions in investment plans triggered by the vote. Our measurement arguably reveals an important effect of the policy shock by focusing on the uncertainty as perceived by the persons directly involved in the investment decisions of firms. We show that the results are similar if we use a pre-determined measure of exposure to the reform.

\footnotetext{
${ }^{1}$ Migration quotas are incompatible with the Free Movement of Persons (FMP) Agreement of Switzerland with the EU/EFTA countries. The FMP Agreement is tied to six other economically relevant bilateral agreements Switzerland has with the EU in the areas technical barriers to trade, agriculture, public procurement, overland transport, civil aviation and research. Renouncing one agreements is likely to terminate all seven agreements.
} 
Our results suggest that firms experiencing an increase in uncertainty significantly reduced their investment plans because of the vote relative to those firms that did not experience an increase in uncertainty. Similar to Guiso and Parigi (1999), we find these negative effects to be concentrated among those firms that would find it costly to resell their physical capital and have therefore difficulties reversing their investment decisions. This is consistent with the "wait-and-see" or real option theory formulated among others by Bernanke (1983), Pindyck (1988) and Caballero (1991), who predict that firms that cannot reverse their investment without incurring costs do engage in a wait-and-see behaviour when faced with increased uncertainty. Consequently, we also find that the negative effects of policy uncertainty on investment plans are concentrated on machinery and equipment investment relative to construction investment. Whereas the first are often quite firm specific, it is generally easier to resell buildings. Further, we find that uncertainty mainly dampened firms' plans to extend their production capacities, while other types of investment such as replacement investment were not affected.

The remainder of the paper is organized as follows: Section 2 looks into the relevant literature on uncertainty. Section 3 discusses the Swiss setting and in particular the Mass Immigration Initiative. In Section 4, we describe our model and the hypotheses we want to test. Section 5 subsequently describes the data and Section 6 presents and discusses the main results. After discussing some robustness checks in Section 7, Section 8 summarizes some additional evidence regarding longer-term impacts on investment. Section 8 concludes.

\section{Literature on Uncertainty}

Uncertainty is an ambiguous concept. ${ }^{2}$ Moreover, the distinction between uncertainty and risk is not clear-cut. Both concepts relate to the variance of a forward-looking variable. According to Bernanke (1983), the relevant concept for investment decisions is uncertainty in the sense of Knight (1921). Knight defines risk as a known probability distribution over a set of events. In contrast, uncertainty is the unreducible part of ignorance about future events, i.e. defined as people's inability to foresee the likelihood of certain events. Generally, theory assumes that new information relevant to judging investment returns arrives over time such that uncertainty about future events decreases.

\footnotetext{
${ }^{2}$ An overview of different concepts of uncertainty and the often subtle distinctions can be found in Hansen (2014).
} 
Therefore, it might be optimal for an investor to await new information before investing. In particular, the real option theory suggests that uncertainty reduces investment, but only if investments are irreversible (i.e. are costly to reverse; see Bernanke, 1983, Pindyck, 1988 and Caballero, 1991). According to this theory, if investments would be perfectly reversible, then risk neutral firms facing increased uncertainty should actually increase their investment activities because of an asymmetry in expected costs and gains: while expected costs are bounded, expected gains are not. Therefore, an increase in uncertainty, i.e. an increase in the variance of losses and gains, should lead to a higher expected return on investment. This result is swamped when investments are (partial) irreversible and a leeway of timing exists. The literature compares the possibility to invest to holding a financial call option, only that the underlying asset is not a stock but rather an investment project. Executing an irreversible investment project kills a firms' option of future investment possibilities. A rise in uncertainty thus increases the probability of committing to suboptimal investments. The associated expected costs might outweigh the benefits of investing immediately and lead firms to pause their investment activities. ${ }^{3}$

Several studies have provided empirical evidence in favour of the wait-and-see behaviour projected by real option theory. Pattillo (1998) constructs an uncertainty measure using a firm's self-reported probability distribution about expected demand. He finds that uncertainty raises the firm-specific threshold of expected marginal revenue that triggers investments. Similarly, Guiso and Parigi (1999) proxy uncertainty using the variance of a firm's self-reported probability distribution about future demand. They find that uncertainty decreases firm investment among Italian firms. Additionally, they find that the negative effect of uncertainty on investment is stronger for firms with higher market power and more irreversible investment projects. $^{4}$

In fact, the effects of uncertainty have received increasing attention in recent years. One reason for this surge in literature is, according to Bloom (2014), the jump in uncertainty in 2008 and its presumed role of actively influencing the Great Recession. Moreover, technical developments, such as increasing computing power and the digitalization of news, has led to an increase in the possibility to measure and estimate the effects of uncertainty (Bloom, 2014).

\footnotetext{
${ }^{3}$ See Dixit and Pindyck (1994) for a deeper elaboration on this topic.

${ }^{4}$ More recent studies investigating how uncertainty affects the real economy include Bloom et al. (2007), Fuss and Vermeulen (2008), Bloom (2009), Bontempi et al. (2010), Bachmann et al. (2013), Bachmann and Bayer (2013), Bianco et al. (2013) and Kang et al. (2014).
} 
Consequently, researchers have used a variety of uncertainty measures. The most prominent ones include capturing sentiment in newspapers, dispersion of professional forecasters, firm assessment using survey data and volatility measures in equity and bond markets. ${ }^{5}$

There are two main concerns with the available uncertainty measures. The first is that they may not only measure uncertainty, but are also affected by other factors. For example, Bekaert et al. (2013) show that risk aversion affects the VIX - a measure of implicit stock market volatility and a popular financial markets instrument for measuring uncertainty. Along similar lines, Jurado et al. (2015) show that another stock market volatility measure, the VOX, varies for many reasons unrelated to broad-based macroeconomic uncertainty. It is thus often unclear whether studies using these measures capture the effects of uncertainty on economic activity or the effects of a third variable that correlates with uncertainty over the business cycle. A second concern with the uncertainty measures is that it is often unclear what kind of uncertainty they actually capture, making it difficult to derive clear policy recommendations from them. For instance, uncertainty triggered by a natural disaster might have different consequences than that triggered by a sudden change in policy.

To better isolate causal impacts of uncertainty on economic outcomes and to understand how different types of uncertainty affect the behaviour of firms, a recent branch of the literature has thus started to study situations in which there is an exogenous and known shock to uncertainty. For instance, Julio and Yook (2012) use electoral cycles to identify effects of policy uncertainty. Baker and Bloom (2013) propose to use natural disasters, terrorist events and policy shocks to identify the impacts of uncertainty. Stein and Stone (2013) exploit exogenous variation in energy prices.

This paper follows the lead of these studies and analyses how the unexpected acceptance of an important and far-reaching popular initiative in Switzerland on February $9^{\text {th }}, 2014$ affected investment plans of Swiss firms. Firm surveys before and after the shock allow us to analyse to what extent firms that were more or less affected by the vote adjusted their investment plans. Our data also enable us to study the driving forces behind these adjustments.

\footnotetext{
${ }^{5}$ Examples of studies that use sentiment in newspapers to study the effects of investment include Baker et al. (2015), Iselin and Siliverstovs (2013), Abberger et al. (2014) and Iselin (2015). Studies using dispersion of professional forecasters are, e.g., Bomberger (1996), Boero et al. (2008) and Baker et al. (2013). For examples of studies using firm assessment in survey data, see Guiso and Parigi (1999), Bachmann et al. (2013), Bianco et al. (2013), Binding and Dibiasi (2016). Bekaert et al. (2013) is an example of a study using volatility measures in equity and bond markets.
} 
In studying this question, our paper adds to the growing literature that focuses on the effects of economic policy uncertainty. An important recent contribution on this relationship is Baker et al. (2015) who focus on the measurement of economic policy uncertainty. ${ }^{6}$ Their firm-level analysis also shows that economic policy uncertainty as measured through newspaper searches has direct negative consequences on firms' investment and employment in policy-sensitive sectors like defense, healthcare, and infrastructure construction. Our study complements their analysis by focusing on the impacts of a sudden and sizeable shock in policy uncertainty using an event-based approach and by measuring the exposure to this shock using survey methods. Moreover, we extend their analysis by being the first to pin down the effect of uncertainty to an unexpected and still unclear amendment of the constitution. The circumstances that we study are very specific: the initiative effectively introduced an expiration date for the uncertainty in the constitution by clearly specifying when the new regulations have to be put in place. The setting thus allows us to study whether uncertainty that can be expected to be resolved has an influence on real economic activity.

\section{The Swiss Setting}

During the past decade, Switzerland has experienced a substantial immigrant inflow. In between 2002 and 2012, the average annual gross immigrant inflow relative to the resident population amounted to $1.6 \%$. As the largest part of the incoming migrants came for work reasons, the average annual gross immigrant inflow into the labour force in this period was $3.2 \%$. This new immigration wave into Switzerland raised anti-immigration sentiments in the population.

In 2011, the Swiss People's Party (SVP), a national conservative party, thus started an "initiative" aiming at restricting immigration, the so-called "Stop Mass Immigration Initiative". The initiative demands a reintroduction of an annual cap on total immigration into Switzerland, similar to the system Switzerland had in the 1990s. These limits and quotas should apply to all permits covered by legislation on foreign nationals and must be geared towards

\footnotetext{
${ }^{6}$ Important earlier studies on the effects of policy uncertainty on investment are Rodrik (1991) and Hassett and Metcalf(1999). These papers investigate how the real economy reacts on uncertainty caused by changes in the regulatory environment. More recently, Born and Pfeifer (2014) and Fernandez-Villaverde et al. (2015) purse the question if policy uncertainty affects the real economy within DSDG framework. Both find weak negative effects.

${ }^{7}$ An "initiative" is a constitutional instrument in Switzerland and represents a cornerstone of Switzerland's direct democracy. It allows people to suggest a law at the federal, cantonal or municipal level. Hence, these popular initiatives do not originate from the parliament or government, but from the citizens themselves. At the national level, citizens must collect signatures of 100,000 voters within 18 months for an initiative to be organized and put to ballot.
} 
Switzerland's overall economic interests. The initiative also demands that businesses must give Swiss nationals priority when hiring staff.

Reintroducing quotas on total immigration is incompatible with Switzerland's Free Movement of Persons Treaty (FMP) with the EU/EFTA states. The since June 2002 gradually introduced free movement regime has lifted restrictions on EU citizens wishing to work in Switzerland and vice versa. The initiative is at odds with the FMP because it limits the access of foreign workers to the country and discriminates between resident workers and EU nationals. Furthermore, the FMP is linked to six other bilateral agreements Switzerland has with the EU. These bilateral agreements concern, among others, road and air traffic, agriculture, and technical trade barriers. Importantly, the agreements are mutually dependent through a socalled Guillotine clause, i.e. if any one of them is renounced or not renewed, they all cease to apply - or at least need to be renegotiated. It is widely believed that these agreements have contributed to the comparatively strong economic performance of Swiss firms during the last decade. $^{8}$

Although the initiative was debated controversially prior to the vote, it was generally believed that the majority of voters would reject it. First, popular initiatives are more often rejected than accepted. Between 1980 and 2015, only 15 out of 125 popular initiatives received the majority of votes. Second, none of the other major political parties, no trade union, no employer organization and only very few media outlets in Switzerland supported the initiative. Third, Switzerland's citizens have always voted in favour of the bilateral agreements in prior votes where the so-called "bilateral way" was put into question. Fourth, all popular polls on the initiative indicated that it would not find a majority. The last official poll, financed by the publicly owned television, was published two weeks before the vote took place. It saw $50 \%$ percent of the voters against the initiative and $43 \%$ in favour of it, with $7 \%$ not yet decided on how to vote. Since support for popular initiatives generally declines when the Election Day approaches, these results were generally interpreted as an indication that the electorate would reject the initiative (see, e.g. GFS, 2014). The vote itself took place on February $9^{\text {th }}, 2014$. A

\footnotetext{
${ }^{8}$ The FMP has been central for Switzerland's economy in the past decade. It has enabled firms to address labour shortages in the resident workforce by attracting foreign workers (Siegenthaler et al., 2014). This led to a substantial immigration wave that fuelled demand for local products and services and allowed firms to grow to an extent that would not have been possible without the treaty (Ruffner and Siegenthaler, 2015). Abberger et al. (2015) provide a thorough assessment of the importance of these agreements for the Swiss economy.
} 
close $50.3 \%$ percent of all voters (with a voter turnout rate of $56.6 \%$ ) and the necessary majority of the 26 cantons accepted the constitutional amendment demanded by the initiative.

This unexpected result received a substantial amount of media interest. The Neue Zürcher Zeitung, a renowned newspaper in Switzerland, wrote in an editorial article that the result represents a "slap in the face" of the political elite in Switzerland and a "caesura for Switzerland". Many leaders of EU countries expressed their concerns about the outcome. For instance, the German chancellery published a statement saying that it "recognizes and respects the result, but it is nevertheless clear that it creates considerable problems." The international importance of the vote was also recognized in a retrospective article in the New York Times on February $26^{\text {th }}, 2014$, saying “the referendum [...] sent shock waves across Europe."

This unexpected outcome created overnight a substantial amount of policy uncertainty regarding the legal (and political) environment for Swiss firms that has four interconnected layers. First, the new constitutional text is vaguely formulated, creating uncertainty about how Swiss immigration policy might look like in the future. The initiative neither specifies how high the new quotas will be, nor who should set and allocate them and according to what criteria. Second, the initiative creates uncertainty about the future supply of workers for firms in Switzerland. The possibility to fill open vacancies with workers from EU/EFTA countries is likely to be limited in the future. Third, the initiative creates demand uncertainty for domestic firms. With the acceptance of the initiative, the demand for local goods and services that has so far been created by the substantial inflow of immigrant is potentially breaking away or at least not going to grow as fast as in recent years. Fourth, due to the Guillotine clause, it remains unclear whether or to what extent the other bilateral agreements will remain in place in the future. The vote thereby questions the cornerstone of Switzerland's foreign and economic policy since the mid-1990s. Most importantly, it creates uncertainty about the firm's future access to the EU market. The preferential access to the EU single market for goods is at risk. This is a substantial risk, because the EU is representing Switzerland's main export market with $55.6 \%$ of total exports in 2012 .

As argued in Section 2 and in accordance with real option theory, an increase in uncertainty will have negative consequences for investment if two conditions are fulfilled (Bernanke, 1983). First, it must be possible to resolve uncertainty by waiting. Second, it is necessary for investment to be irreversible to some degree. Our case fulfils these conditions: A new immigration policy along the lines of the initiative has to be implemented within three years 
(i.e. by February 2017). Therefore, at the latest early 2017, firms will know how the new constitutional amendment is implemented. Second and as we will document later, the investment activities of firms are at least partially irreversible.

\section{Empirical Model and Hypotheses}

The distinctive political system in Switzerland and the largely unexpected outcome of the popular initiative against mass immigration led to a rare setting in which one can test hypotheses about the effect of uncertainty on firms' investment decisions. In particular, we think that the acceptance of MII, which led to an adaption of firms' demand expectations, significantly shaped the probability distribution of future business conditions. Firms are likely to have adjusted their investment plans to their new expectations. In line with real option theory, we thus test the following main hypothesis:

Firms that experience an increase in uncertainty and face (partial) irreversible investment decisions reduce their investment plans.

To understand how we assess this hypothesis empirically, we need to elaborate shortly on the structure of our data. We conduct our analyses using data from the investment surveys of KOF Swiss Economic Institute at ETH Zurich, which conducts this survey bi-annually among a large panel of private firms. Our analysis is largely based on data from two surveys. Figure 1 provides a schematic representation of the timing of the data collection for these surveys relative to the referendum (which took place on February 9, 2014). As illustrated by the Figure 1, KOF collected the data for the investment survey in autumn 2013 between October 7 and December 31, 2013 (1.5-4 months prior to the vote). In spring 2014, KOF sent out questionnaires on February 25, 2014. The survey lasted until May 5, 2014 such that the data is from 2 weeks to 3 months after the vote. ${ }^{9}$

One important feature of each of these surveys is that firms are asked about their investment for several years. For instance, in the survey in autumn 2013, firms were asked for quantitative information on investment activity in 2012, 2013 and 2014. Some of the investment data are hence actual investment made in the past, and some of the data refer to planned investment in the current and next year. Table 1 illustrates how our empirical analysis exploits this feature. In particular, firms reported their actual and planned investment plans for the years 2013 and

\footnotetext{
${ }^{9}$ For reason we will explain below, we will, in the robustness section, occasionally resort to information collected during the investment survey carried out in autumn 2014. This survey took place around 9 months after the vote.
} 
2014 in both the survey in autumn 2013 and the one in spring 2014. However, while in autumn 2013 they most likely expected the MII to be rejected, in the spring survey the MII had been unexpectedly accepted. Our focus is thus to quantify the extent to which firms revised their investment plans for 2014 because of the MII.

However, a first challenge in the empirical analysis is that the policy uncertainty caused by the vote potentially affected firms in the spring survey differently. Our preferred method to identify the effect of the vote on the micro level is to directly ask firms whether their certainty of eventually conducting their investment plans is affected by the MII, i.e. we study whether firms that reported to be affected by uncertainty due to the initiative adjusted their investment plans differently than those that reported not to be affected. This measure arguably pinpoints firms whose investment certainty changed as a consequence of the initiative, thus allowing a direct evaluation of the revisions in investment plans triggered by the vote. A potential problem of this identification strategy is that the persons responsible for firms' investment decisions may not be able to disentangle the factors that affect their investment plan revisions, such that the answer to the survey question captures a bundle of factors affecting their investment plan revisions. This danger is arguably limited because the MII represents by far the most important macro-level shock that affected the firms in the short period between the two surveys.

Nevertheless, as a robustness check we also gauge the impact of the vote by differentiating between firms that differed in their pre-determined exposure to the vote. In particular, we exploit that firms with a high share of foreign workers in total employment were more strongly exposed to the policy uncertainty shock than firms with a low foreign share, as the initiative directly puts into question the access of Swiss firms to the pool of foreign workers in the future. The identifying assumption in this case is that firms with high and low foreign employment share would have revised their investment plans equally between the two surveys in the absence of the vote. We are not aware of a change in an unexpected macro-level shock occurring between autumn 2013 and spring 2014 that differentially affected firms with high and low foreign workers shares.

A second challenge in the analysis is to disentangle the impact of MII on investment plans through changes in uncertainty from the impact that is triggered by changes in the mean of the expected demand. We thus follow previous papers (such as Baker et al., 2015) and control for the first order demand effect in the regression. In particular, we include a variable revealing whether firms think that their demand development was affected by the vote. 
Putting these elements together, we estimate the following baseline equation:

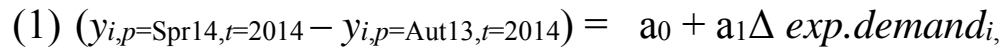

$$
\begin{aligned}
& +\mathrm{a}_{2} \Delta \text { uncertainty, }
\end{aligned}
$$

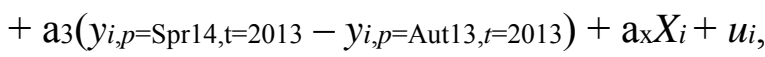

where $y i, p, t$ stands for the $\log$ investment for year $t \epsilon(2013,2014)$ as observed in survey $p \epsilon$ (Autumn 2013, Spring 2014) by firm $i$. The variable $\Delta$ exp.demandi, measures the self-reported impact of the initiative on expected demand (first moment) and takes the value one if a firm states that a firm perceives a decline in expected demand due to the policy shock and zero otherwise. We expect that firms that perceive a negative shift in demand due to the vote are likely to reduce their investment plans relative to other firms. The variable $\Delta$ uncertainty $_{i}$, is the variable of interest and measures an increase in the second moment of their expected demand due to the vote. It equals one in case a firm experiences an increase in uncertainty due to the MII and zero otherwise.

Our baseline specification contains a vector of individual firm characteristics $\left(X_{i}\right)$ such as size, sector, export share and region. Conditioning a firm's investment revision on a set of firm controls increases the precision of our estimates and reduces possible omitted variable biases.

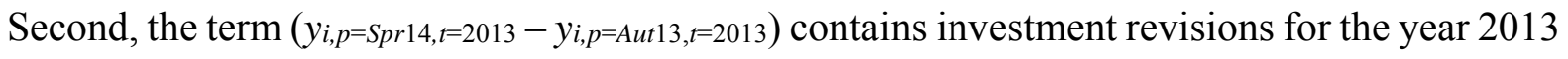
(see Table 1). Firms' revisions to their investments in 2013 should not be - and, as we will show, indeed do not seem to be - affected by the outcome of the vote. Thus, including this variable allows us to account for unobserved firm-specific shocks that affected firms' investment behaviour for 2013 between autumn and the spring survey. Finally, due to our focus on revisions (a first-difference outcome), we account for all unobserved factors that affected firms' investment plans for 2014 in both surveys to the same extent. Examples of such factors are predetermined variables such as investment in the years before.

According to real option theory, uncertainty influences investment plans of a firm only negatively if planned investment are costly to reverse. To test this prediction empirically, we augment our baseline specification with information on the degree of irreversibility of firm's investments. However, it is difficult to observe capital adjustment costs and its (a-)symmetries directly. In the spirit of Guiso and Parigi (1999), our special survey thus contained a question on the second-hand market conditions for existing production plants and machineries. We use this information to construct a firm-specific irreversibility proxy. The dummy variable irreversibility $y_{i}$ takes the value one in case a firm has irreversible investment and zero otherwise. 
We then add an interaction term of the variable $\Delta$ uncertainty $_{i}$ with the variable irreversibility in our regression framework:

(2) $\left(y_{\left.i, p=S p r 14, t=2014-y_{i, p}=\text { Aut13,t=2014 }\right)=\mathrm{a}_{0}+\mathrm{a}_{1} \Delta \text { exp.demand }}+\mathrm{a}_{2} \Delta\right.$ uncertainty $_{i}$

$+\mathrm{a} 3\left(y_{\left.i, p=\operatorname{Spr} 14, t=2013-y_{i, p}=\mathrm{Aut} 13, t=2013\right)}\right.$

+ a4irreversibilityi

$+\mathrm{a}_{5}\left(\Delta\right.$ uncertainty $_{i}{ }^{*}$ irreversibility $\left._{i}\right)+\mathrm{a}_{\mathrm{x}} X_{i}+u_{i}$.

This is our preferred specification. Real option theory expects the coefficient of the interaction term as to be negative. Furthermore, the same theory predicts that when investments are fully reversible the effect of uncertainty on investment plans should be non-negative (i.e. a2 should be non-negative). There is no clear theoretical prediction regarding the sign of a4, the coefficient in front of our irreversibility $i$ variable.

\section{Data - KOF Investment Survey}

As mentioned above, our empirical analysis is based on data from the bi-annual KOF investment surveys. In spring 2014, KOF added additional survey questions to the regular investment survey in order to study the effects of the referendum. These special questions directly asked about the expected consequences of the referendum for future investment activities plans. Furthermore, these surveys asked firms directly whether the acceptance of the MII influenced the uncertainty surrounding their investment plans. The questionnaire also collected certain firm characteristics relevant for the empirical analysis, such as the extent to which investments' are irreversible. We added the questionnaires in Appendix B.

Table 2 provides detailed information on the composition of the firm sample, turnout and the firm sample ultimately available for our study. In the following, we discuss the variables used in the analysis in greater detail.

\subsection{Dependent Variable}

We measure the investment consequences of the vote using the difference in log firm investment plans for 2014 when comparing firm-specific answers in the survey conducted in spring 2014 with those in autumn 2013. In particular, the investment survey conducted by KOF Swiss Economic Institute asks firms to provide investment plans separately for investment in equipment and machinery and investment in construction (see Error! Reference source not found.). Consequently, we quantify by how much a firm revised their investment 
plans for machinery and equipment and their construction plans between autumn 2013 and spring 2014.

The design of the questionnaire does not allow us the discrimination between a firm reporting zero investment and a firm not answering a specific question at all (item non-response). The reason being that the questionnaire prepopulates the quantitative investment questions with zero (see questionnaire in Appendix B). This makes it impossible to distinguish between a participant that did not want to state its investment and one that wanted to communicate zero investment. We therefore ignore all firms reporting zero investment in our main results. However, Table A.2 in Appendix A contains specifications that includes such zero entries. The results do not change in any significant way.

\subsection{Measuring Changes in Expected Demand Levels}

The survey in spring 2014 asked firms how the acceptance of the MII affected the growth potential of Switzerland. Survey participants could choose one of the following options: "strongly decreased", “decreased", "not changed", “increased" or "strongly increased". ${ }^{10} \mathrm{We}$ use these answers to proxy the change in expected demand. We create a variable that takes the value one in case a firm expects Swiss growth potential to decrease and zero otherwise. ${ }^{11}$

\subsection{Measuring Changes in Firm-Specific Uncertainty Related to Investment Decisions}

The literature presents various ways to measure firm-specific uncertainty. Our approach is a direct one: we ask firms directly whether the reform affected their investment (un)certainty or not. To be precise, the special survey in spring 2014 contained a question that asked survey participants how the certainty of their investment plans had changed due to the acceptance of the initiative. ${ }^{12}$ We use the answer of this question to proxy firm level second moment shifts in expected demand.13 Firms could answer on a 5-item Likert-scale: "strongly decreased", "decreased", "not changed", "increased" and "strongly increased". Overall, 143 of 956 firms $(15 \%)$ in our estimation sample reported that the initiative increased or strongly increased

\footnotetext{
${ }^{10}$ See the questionnaire in Appendix B for the exact wording.

${ }^{11}$ Although we use only a one-zero variable in the estimations, it is advantageous to give the respondents a finer Likert scale. This reduces the risk of a central tendency bias in the answering behaviour.

${ }^{12}$ See the questionnaire in Appendix B for the exact wording.

${ }^{13}$ For theoretical reasons we refer to demand as our central variable affected by the MII. However, besides demand, the acceptance of MII did also influence expected labour supply and in particular high-skilled labour supply. Assuming capitallabour complementarity, uncertainty about future labour supply affects investment in a similar way as uncertainty about future demand.
} 
investment uncertainty. Using this survey question, we consider firms as "uncertain" if they reported an increase in investment uncertainty due to the acceptance of the initiative.

\subsection{Measuring Firm-Specific Irreversibility of Investment Decisions}

In order for uncertainty to affect investment theoretically, some degree of irreversibility of investments is required (Bernanke, 1983). If an investment is perfectly reversible, changes in uncertainty should have no negative (or even a positive) effect on investment. Based upon Guiso and Parigi (1999), we added a question to a follow up survey that allows us to infer the degree of irreversibility of firm investments. ${ }^{14}$ We allow four answering options going from fully reversible to not reversible at all, whereby the two categories in between allow a differentiation according to the time required, the difficulty, and the expected price received when reselling equipment and/or machinery. Hence, to measure irreversibility a scale similar to a Guttman scale instead of a Likert scale is used.

Figure 2 displays the distribution of the reported irreversibility by the firms in our sample. In our sample, only approximately $5 \%$ of the firms indicate full reversibility. The overwhelming majority of firms indicate at least a certain degree of irreversibility. We designate firms as having high or low irreversibility similar to Guiso and Parigi, i.e. firms indicating that it is easy or only takes some time to sell their equipment and/or machinery (1 and 2) are attributed high reversibility, while those indicating that it is very difficult or that there is no market for their equipment and/or machinery (3 and 4) are attributed low reversibility. The majority (345) of all firms indicated that re-selling equipment and/or machinery is very difficult but not impossible, while 231 firms indicated that re-selling is possible within a short period. 328 firms indicated that there is no market for their equipment and/or machinery.

\subsection{Other Control Variables}

In our regressions, we also control for additional firm characteristics in order to avoid omitted variable issues. First, we control for the firm size by taking into account the number of fulltime equivalent employees (FTE) the firm reported having on December 31, 2013. ${ }^{15}$ Second,

\footnotetext{
${ }^{14}$ KOF Swiss Economic Institute added an ad-hoc survey on the consequences of MII also in autumn 2014. The overlap with the ad-hoc survey in spring 2014 is large. However, the questionnaire did contain two additional questions. One questions levied information on a firm's degree of irreversibility. The second question asked how the acceptance of MII change the expected value of a firm's future demand.

${ }^{15}$ The survey asks firms to report their number of full time equivalent employees in each wave. In the spring survey, firms report the number of FTE employees on December 31 of the previous year. In the autumn survey, firms state the number of FTE employees on June 30 of the same year. Hence, we control for the number of FTE a firm had before the referendum, i.e. the outcome of the vote did not influence the number of employees.
} 
we control for the share of exports a firm had prior to the vote. Information on the export shares of firms is taking from the investment survey of autumn 2013. We can distinguish between four different export classes: firms with an export share between $0-5 \%$, between 6-33\%, between 34-66\% and between 67-100\%. Finally, we add sector (NACE 2-digit industry levels) and region controls (NUTS 2 regions).

\section{Main Results}

Table 3 provides summary statistics on the variables used in the empirical analysis. It also provides their sample means separately for firms that report an increase in uncertainty due to MII and firms that do not.

The comparison of the means across the two groups reveals two important findings. First, uncertain firms are on average also more likely to expect a decrease in demand due to the vote and are more strongly engaged in exporting than firms that do not report decreased investment certainty (as indicated by the two-sample t-test reported in the last column of Table 3, testing the equality of the two means). On the other hand, uncertain and certain firms are not significantly different in terms of size and the degree of irreversibility of their investment. Second, the comparison suggests that uncertain firms lowered firms' plans to invest in 2014 relative to certain firms. In particular, the difference in the revisions of investment in equipment and machinery between the two groups is sizeable. It amounts to almost 10 percentage points and it is statistically significant. The difference in the average revision for construction plans between the two groups also amounts to five percentage points, but is not statistically significant. Note, however, that we cannot deduce an accurate picture of the actual effect of uncertainty on investment from a comparison of unconditional means as it does not condition on important factors such as first moment changes in firms' expected demand.

Therefore, we now elaborate whether these unconditional findings on the effect of uncertainty on firm-level investment plan revision are also visible within a regression setup. Table 4 summarizes our main findings. Columns 1 to 4 of Table 4 report the estimation results of our main specifications (Equations 1 and 2) separately for revisions in investment in machinery and equipment and investment in construction. All regressions account for a full set of industryand region fixed effects.

Column 1 of Table 4 provides first evidence that uncertainty influences investment in equipment and machinery. The estimated coefficient suggests that firms that experience 
decreased investment certainty due to the vote lower their investment in machinery and equipment in 2014 by 5.8 percentage points. Column 3 augments the baseline model with an interaction term proxying for the degree of irreversibility of firms' investment. As expected, we find a negative coefficient of the interaction term 'Irreversibility $x$ Uncertainty'. The statistically significant coefficient suggests that uncertain firms with irreversible investment lowered their investment in equipment for 2014 on average by about 13 percentage points relative to certain firms and relative to firms with reversible investment in machinery and equipment (i.e. with Irreversibility=0). The latter do not appear to adjust their investment plans because of the uncertainty, consistent with the predictions from real option theory. We consider the magnitude of this uncertainty effect as sizeable.

Columns 2 and 4 show that we do not find equivalent uncertainty effects for construction investment. The coefficient on both, the dummy indicating increased uncertainty and the interaction term are not statistically different from zero at any conventional significance level. ${ }^{16}$ This result is consistent with our expectations. First, construction investment is mostly reversible, i.e. there is a larger market for (re-)selling construction investment (most importantly, buildings) than there is for (firm-specific) machinery and equipment. This is not mirrored in a statistically significant interaction between Irreversibility and Uncertainty' in Column 4 because our firm-specific irreversibility variable captures only the degree of irreversibility of machinery and equipment. Second, changing construction plans is costly and requires time. Thus, the time lag between planning and realisation is on average longer in the case of construction investment, for instance because construction investment require several permissions by the authorities. To the extent that construction plans are already settled, the uncertainty shock caused by the vote is unlikely to impact on this investment component shortly after the vote.

In Columns 5 and 6, we assess whether the uncertainty caused by the vote has a stronger impact on extension investments rather than any other type of investment (such as replacement investments or investment that aim at streamlining production or fulfilling regulatory requirements). We expect a stronger effect on extension investment because extending the production capacity can be delayed more easily and arguably entails a higher risk of turning

\footnotetext{
${ }^{16}$ Our dataset neglects all firms reporting zero investment for 2013 or 2014 in at least one of both survey waves. This means, our results are conditional on the decision of a firm to invest. This fact could potentially bias our results in a way that firms deciding to pause their investment, hence report investment of zero for 2014 in the spring 2014 survey, are not included in our sample. However, if at all, this bias implies that we (in an absolute sense) underestimate the negative impact.
} 
out wrong in the future than other types of investment. Using a survey question on firms' investment motives in the survey in autumn 2013, we identify firms that planned extension investments in 2014. We then include the variable Extension investment planned and an interaction of this variable with the uncertainty indicator into our baseline model (Equation 1). The results of this regression suggest that the uncertainty caused by the vote only affected firms that planned extension investments in machinery and equipment in 2014 (Column 5). Again, there is no equivalent impact of uncertainty on construction investment although the estimated coefficients have the expected signs (Column 6).

\section{Robustness}

The results in the last section suggest that the uncertainty created by the acceptance of MII lowered irreversible investment in machinery and equipment. We test the robustness of this finding in several ways. Overall, we re-estimate six variants of our main specification. ${ }^{17}$ Table 5 presents the estimation results.

We start our robustness analysis with a placebo test. In particular, we test whether firms reporting, or not reporting, increased uncertainty due to the MII differ in the way they changed investment plans in 2013 between the surveys in autumn 2013 and spring 2014. Since the investments in 2013 are posterior to the vote, these revisions should not be affected by it. Column 2 of Table 5 indeed shows that we do not find a statistically significant association of our uncertainty variable (Increased uncertainty) and its interaction with irreversibility on revisions of investment plans in $2013 .^{18}$

Column 3 tests whether our results depend on our proxy for the first moment changes in expected demand. In our main model, we proxy the first moment shift in firm-level demand expectation with a firm's expected change of the Swiss growth potential. The Swiss growth potential is not firm-specific and might be a weak proxy for first moment changes of a firm's subjective expectation on future demand. We thus replace our initial proxy with an alternative measure constructed using an additional survey that was conducted in autumn 2014 (see Figure

\footnotetext{
${ }^{17}$ Table 1 shows that the average response rate was higher for manufacturing firms than for firms in the construction or service sector. This leads to a slight overrepresentation of manufacturing firms in our sample. We also conduct a non-response analysis to study how non-response affects our estimates. We do this by presenting an estimation of our baseline model in which we re-weight observations by the inverse of the firms' probabilities to respond to the survey, i.e. firms with a low response probability get a higher weight in this estimation. Table A.1 in Appendix A presents the results of these estimations and shows that the conclusions do not change in any significant way.

${ }^{18}$ This holds despite the fact that the revisions in investment plans between the two surveys are highly correlated for both 2013 and 2014, as can be seen by the highly statistically significant coefficient on the lagged investment revision variable in Column 1.
} 
1). The ad-hoc questionnaire added to the regular investment survey contained a question that directly and specifically asked firms how the acceptance of MII affected their own expected demand. We construct a binary variable that takes value one if MII lowered the expected demand of a firm and zero otherwise, and re-estimate our main model. Table 5 shows that using this alternative variable to account for the first moment shift in firms' expected demand does not change the coefficients of interest in any relevant way.

Column 4 tests whether we can replicate our results when replacing the qualitative, selfreported survey question indicating firms that perceive to be uncertain (i.e. Increased uncertainty) with a pre-determined firm-specific characteristic determining exposure of a firm to the unexpected outcome of the referendum. In particular, we build a dummy equal to one if a firm has a share of foreign workers in total employment that belongs to the top $25 \%$ of all firms. ${ }^{19}$ We then include this variable as well as interactions with Irreversibility and Demand decrease into our main specification. Column 4 presents the results. The regression shows that firms with irreversible investment and a high share of foreign workers revised their planned investment in machinery and equipment for 2014 downward in the survey in spring 2014. This suggests that the vote depressed the investment plans of these firms by having a larger impact on them. As before, we can subject the result from this complementary specification to a placebo test by using investment revisions for 2013 as the outcome of the regression. Firms with high and low shares of foreign workers do not seem to differ in their revisions of their investment plans for 2013, as shown in Column 5.

In Column 6 of Table 5, we neglect data from the survey KOF conducted in the immediate aftermath of the vote (i.e. in spring 2014) and replace it with data from the autumn 2014. In this case, our regression explains firm investment plan revisions for the year 2014 between autumn 2013 and autumn 2014. We hope to address two possible concerns with this modification. First, Swiss media extensively reported on the outcome of the vote and heavily discussed possible implications for the Swiss economy. We fear that the sentiment created by the media might have distorted firms' perceptions such that data from the spring survey overstates the effect of MII. Using data from the survey conducted in autumn 2014 puts more space between the vote and data collection and should partly resolve this issue. Second, the acceptance of MII could have led firms to revise their investment plans downward in the immediate aftermath of the vote, but they could have reconsidered such revisions already in

\footnotetext{
${ }^{19}$ The results are qualitatively similar when using other thresholds.
} 
summer 2014 and return to their original investment plans. Using data sampled in autumn 2014 allows us to verify the persistence of the uncertainty shock. Obviously, exchanging spring 2014 data with data from autumn 2014 comes at a cost. The reason is that the probability increases that other factors apart from the vote have influenced investment plan revisions, questioning a causal interpretation of our results. The sixth column of Table 5 shows the results of this robustness test. The findings show that the significant effect of the acceptance of the initiative on irreversible investment plans prevails even around 7 months posterior to the vote. The size of the effect reduces slightly to $10 \%$.

The last two columns provide the results of two further checks. First, we winsorise the outcome variable to examine the extent to which our results are driven by firms with substantial adjustments in their investment plans. This leads to a slight decrease in the precision of the estimates but has no impact on the qualitative results. The last column of Table 5 shows that dropping the export share categories, the firms' number of employees, and the region and industry dummies does not change the coefficients of our main model in a significant way. However, it reduces the precision of the estimates.

\section{Effects on Long-Run Investment Plans}

Table 4 presented empirical evidence that uncertainty caused by MII depressed investment in equipment and machinery for 2014. Hence, the reported findings refer to the immediate consequences of the uncertainty on investment plans. They do not speak about the impact of uncertainty on long-term investment plans. To get an idea whether the vote may have had consequences on firms' longer-run plans in investment in Switzerland, we, in the KOF investment survey in spring 2014, asked firms directly whether their investment plans for 2014, 2015, 2016 and 2017 were affected by MII. Firms were given the possibility to state whether their investments plans "strongly decreased", “decreased", “did not change", “increased" or "strongly increased" because of the acceptance of the initiative (see Appendix B). Based on this categorical variable, we create a dummy variable for each year that is one in case a firm decreased investment plans because of the MII and zero otherwise. ${ }^{20}$ Because the question focuses on a longer time horizon, firms were asked about their overall investment plans

\footnotetext{
${ }^{20}$ Abberger et al. (2014) estimate ordered probit models using a three-level categorical variable indicating decrease, increase or no change of investment. We deviate from their approach as we think a binary variable is easier to interpret. However, results do not change qualitatively if we apply their approach.
} 
(GFCF), i.e. we did not ask firms to distinguish between equipment and construction investment.

We present the findings on the influence of uncertainty on long-term investment plans in Table 6. The coefficients for uncertainty are positive and statistically significant in every specification, i.e. uncertain firms are more likely to reduce their investment plans due to MII than certain firms in all years between 2014 and 2017, suggesting a negative impact of the referendum on longer-term investment plans. Moreover, the negative effect of uncertainty on the propensity to reduce investment plans increases with the time horizon. The coefficient of the interaction term between irreversibility and uncertainty is usually negative, consistent with our previous findings and with the predictions from real option theory. However, it is not statistically significant. One potential reason for this result is that the variable "irreversibility" specifically proxies for irreversibility of existing machinery and equipment only and that, more in general, construction investment is easier to sell on a secondary market.

\section{Conclusions}

By studying the surprising acceptance of a far-reaching popular initiative in Switzerland that has put several economically relevant agreements between Switzerland and its main trading partner, the European Union, at stake, this paper analyses the effects of a rare shock in policy uncertainty on firms' investment plans for the near future. It thereby is the first to use survey data to measure the impact of policy uncertainty on planned investment activities of firms. So far, the most prominent ways of measuring uncertainty include capturing sentiment in newspapers, dispersion of professional forecasters, firm assessment in survey data and volatility measures in equity and bond markets. Our approach to measure uncertainty is more direct and simple. We have asked firms whether the unexpected outcome of the policy vote affected their uncertainty surrounding future investment activities.

According to real option theory especially those firms that face irreversible investment decisions should resort to a wait-and-see behaviour in case of a temporary increase in (policy) uncertainty. Our results indeed suggest that the analysed policy shock did lead to a significant downward revision in firms' investment plans, but only for those firms that experienced an increase in investment uncertainty because of the vote. Furthermore, we find these negative effects to be concentrated among those firms that would find it costly to resell their physical capital and have therefore difficulties reversing their investment decisions. This shows that uncertainty caused by an unexpected and still unclear amendment of the constitution 
immediately reduces firms' investment plans especially when these are difficult to reverse. The amplifying effect of irreversibility is especially visible for machinery and equipment investment. For construction investment, where both the time lag between planning and realisation is longer and there is a larger market for (re-)selling the investments, we do not find significant effects.

Given the high correlation between planned and realised investment activities, it is very likely that the negative effects found will translate in subdued investment activities in Switzerland during the period in which it remains unclear what the consequences of the acceptance of the so-called Mass Immigration Initiative (MII) by the Swiss population will be. Whether this loss in physical capital will also have longer-term consequences on the real economy is beyond the scope of this paper.

\section{References}

Abberger, K., Abrahamsen, Bolli, T., Dibiasi, A., Egger, P., Frick, A., Graff, M., Hälg, F., Iselin, D., Sarferaz, S., J. Schläpfer, M. Siegenthaler, B. Simmons-Süer, J.-E. Sturm und M. Tarlea (2015). Der bilaterale Weg - eine ökonomische Bestandsaufnahme. KOF Studien, 58, Zurich, February 2015.

Abberger, K., Dibiasi, A., Siegenthaler, M., and Sturm, J.-E. (2014). The Swiss Mass Immigration Initiative: The Impact of Increased Policy Uncertainty on Expected Firm Behaviour. KOF Studies, 53.

Bachmann, R., and Bayer, C. (2013). 'Wait-and-See' business cycles?. Journal of Monetary Economics, 60(6), 704-719.

Bachmann, R., Elstner, S., and Sims, E. R. (2013). Uncertainty and Economic Activity: Evidence from Business Survey Data. American Economic Journal: Macroeconomics, 5(2), 217-249.

Baker, S. R. and Bloom, N. (2013). Does Uncertainty Reduce Growth? Using Disasters as Natural Experiments. NBER Working Paper No. 19475.

Baker, S. R., Bloom, N., and Davis, S. J. (2015). Measuring Economic Policy Uncertainty. NBER Working Paper No. 21633.

Bekaert, G., Hoerova, M., and Lo Duca, M. (2013). Risk, Uncertainty and Monetary Policy. Journal of Monetary Economics, 60(7), 771-788.

Bernanke, B. S. (1983). Irreversibility, Uncertainty, and Cyclical Investment. The Quarterly Journal of Economics, 98(1), 85-106.

Bianco, M., Bontempi, M. E., Golinelli, R., and Parigi, G. (2013). Family firms' investments, uncertainty and opacity. Small Business Economics, 40(4), 1035-1058. 
Binding, G. and Dibiasi, A. (2016). Exchange Rate Uncertainty and Firm Investment PlansEvidence from Swiss Survey Data. KOF Working Paper No. 400.

Bloom, N. (2009). The impact of uncertainty shocks. Econometrica, 77(3), 623-685.

Bloom, N. (2014). Fluctuations in Uncertainty. The Journal of Economic Perspectives, 28(2), $153-175$.

Bloom, N., Bond, S., and Van Reenen, J. (2007). Uncertainty and Investment Dynamics. The review of economic studies, 74(2), 391-415.

Boero, G., Smith, J., and Wallis, K. F. (2008). Uncertainty and Disagreement in Economic Prediction: The Bank of England Survey of External Forecasters. The Economic Journal, 118(530), 1107-1127.

Bomberger, W. A. (1996). Disagreement as a Measure of Uncertainty. Journal of Money, Credit and Banking, 28(3), 381-392.

Bontempi, M. E., Golinelli, R., and Parigi, G. (2010). Why demand uncertainty curbs investment: Evidence from a panel of Italian manufacturing firms. Journal of Macroeconomics, $32(1), 218-238$.

Born, Benjamin, and Johannes Pfeifer. Policy risk and the business cycle. Journal of Monetary Economics 68 (2014): 68-85.

Caballero, R. J. (1991). On the sign of the investment-uncertainty relationship. The American Economic Review, 81(1), 279-288.

Dixit, Avinash K., and Robert S. Pindyck. Investment under uncertainty. Princeton university press, 1994.

Fernández-Villaverde, J., Guerrón-Quintana, P., Kuester, K., \& Rubio-Ramírez, J. (2015). Fiscal Volatility Shocks and Economic Activity. The American Economic Review, 105(11), 3352-3384.

Fuss, C. and Vermeulen, P. (2008). Firms' investment decisions in response to demand and price uncertainty. Applied Economics, 40(18), 2337-2351.

GFS (2014), Analyse der eidgenössischen Abstimmungen vom 9. Februar 2014 (VOX. Analyse eidgenössicher Urnengänge). Hauptergebnisse, gfs.bern.

Guiso, L. and Parigi, G. (1999). Investment and Demand Uncertainty. Quarterly Journal of Economics, 114(1), 185-227.

Hansen, L. P. (2014). Uncertainty Outside and Inside Economic Models, NBER Working Paper No. w20394.

Hassett, K. A., \& Metcalf, G. E. (1999). Investment with uncertain tax policy: Does random tax policy discourage investment. The Economic Journal, 109(457), 372-393.

Iselin, D. (2015). Does Negative News Reporting on the Economy Get Reflected in Companies' Business Situation? KOF Working Papers, 388.

Iselin, D. and Siliverstovs, B. (2013). The R-word index for Switzerland. Applied Economics Letters, 20(11), 1032-1035. 
Julio, B. and Yook, Y. (2012). Political Uncertainty and Corporate Investment Cycles. The Journal of Finance, 67(1), 45-83.

Jurado, K., Ludvigson, S. C., and Ng, S. (2015). Measuring Uncertainty. American Economic Review, 105(3), 1177-1216.

Kang, W., Lee, K., and Ratti, R. A. (2014). Economic policy uncertainty and firm-level investment. Journal of Macroeconomics, 39, 42-53.

Knight, F. H. (1921). Risk, Uncertainty and Profit. New York: Hart, Schaffner and Marx.

Pattillo, C. (1998). Investment, uncertainty, and irreversibility in Ghana. Staff PapersInternational Monetary Fund, 522-553.

Pindyck, R. S. (1988). Irreversible Investment, Capacity Choice, and the Value of the Firm. American Economic Review, 78(5), 969-85.

Rodrik, D. (1991). Policy uncertainty and private investment in developing countries. Journal of Development Economics, 36(2), 229-242.

Ruffner, J. and Siegenthaler, M. (2015). From labor to cash flow? Unpublished manuscript.

Siegenthaler, M., Graff, M., and Mannino, M. (2014). The Swiss “Job Miracle”. KOF Working Paper No. 368.

Stein, L.C.D. and E. Stone (2013). The Effect of Uncertainty on Investment, Hiring, and R\&D: Causal Evidence from Equity Options. http://dx.doi.org/10.2139/ssrn.1649108

\section{Tables}

Table 1: Data Structure

\begin{tabular}{|c|c|c|}
\hline \multirow[b]{2}{*}{ Survey $(p)$} & \multicolumn{2}{|c|}{ Investment in year $(t)$} \\
\hline & 2013 & 2014 \\
\hline Autumn 2013 & $y_{i, p}=$ Aut $13, t=2013$ & $y_{i, p}=$ Aut $13, t=2014$ \\
\hline Spring 2014 & $y_{i, p}=\operatorname{Spr} 14, t=2013$ & $\begin{array}{c}y_{i, p=S p r 14, t}=2014 \\
\text { (affected by vote) }\end{array}$ \\
\hline $\begin{array}{l}\text { Revisions in } \\
\text { investment plans }\end{array}$ & $\begin{array}{c}y_{i, p}=\operatorname{Spr} 14, t=2013- \\
y_{i, p=A u t 13, t}=2013\end{array}$ & $\begin{array}{c}y_{i, p}=\operatorname{Spr} 14, t=2014- \\
y_{i, p}=\text { Aut } 13, t=2014\end{array}$ \\
\hline
\end{tabular}




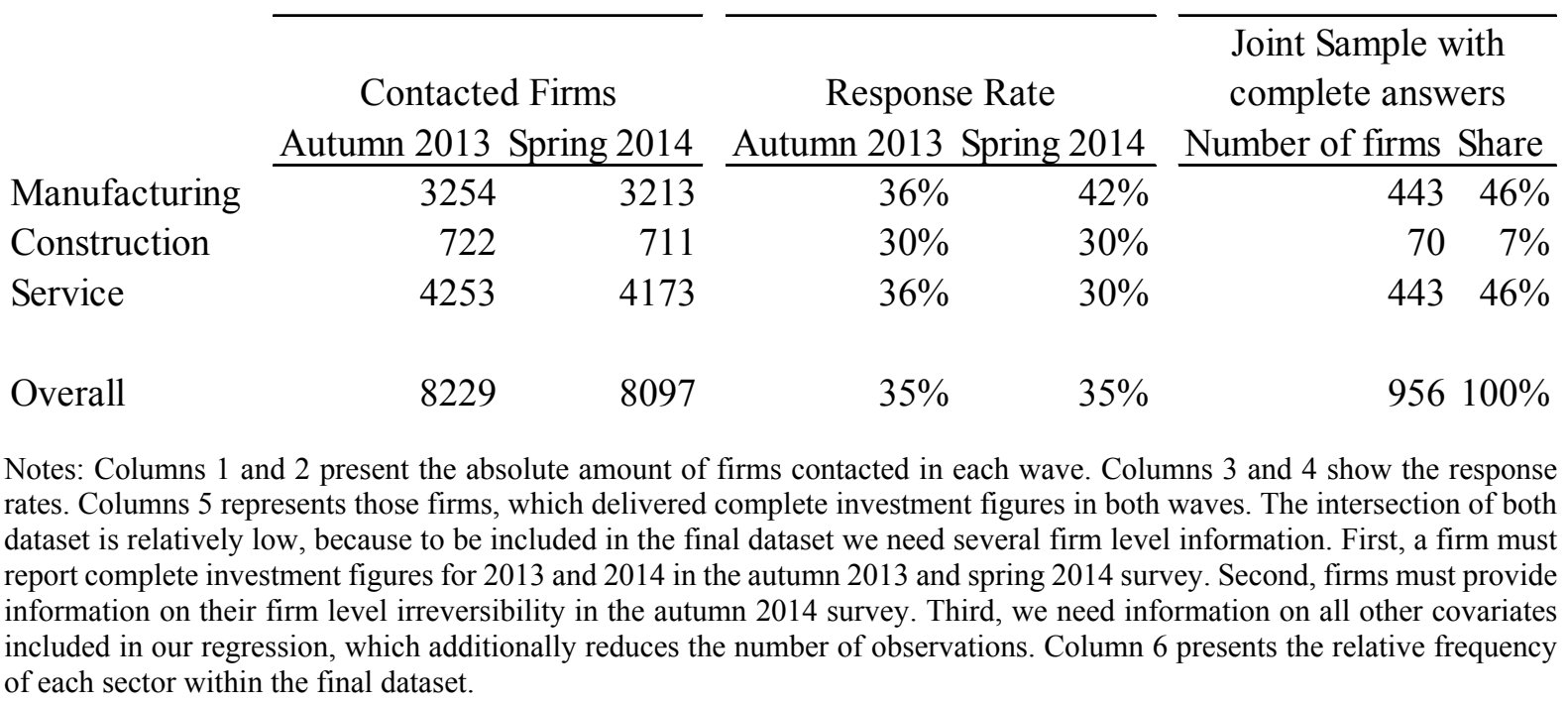

\section{Table 3: Summary Statistics}

\begin{tabular}{lccccccc}
\hline Variable Name & $\mathrm{N}$ & Mean & Median & St. Dev. Mean (Certain) & Mean (Uncertain) & P-Value \\
\hline Growth Rate Revision 2013, Equipment & 887 & 0.011 & 0 & 0.346 & 0.015 & -0.014 & 0.394 \\
Growth Rate Revision 2014, Equipment & 887 & 0.021 & 0 & 0.386 & 0.035 & -0.063 & $0.008 * * *$ \\
Growth Rate Revision 2013, Construction & 445 & 0.021 & 0 & 0.455 & 0.023 & 0.008 & 0.786 \\
Growth Rate Revision 2014, Construction & 445 & 0.020 & 0 & 0.462 & 0.027 & -0.023 & 0.308 \\
Decrease Investment due to MII in 2014 & 937 & 0.019 & 0 & 0.137 & 0.004 & 0.106 & $0.000 * * *$ \\
Decrease Investment due to MII in 2015 & 906 & 0.071 & 0 & 0.256 & 0.019 & 0.371 & $0.000 * * *$ \\
Decrease Investment due to MII in 2016 & 854 & 0.095 & 0 & 0.293 & 0.027 & 0.513 & $0.000 * * *$ \\
Decrease Investment due to MII in 2017 & 826 & 0.091 & 0 & 0.287 & 0.027 & 0.509 & $0.000 * * *$ \\
Number of FTE on 31.12.2013 & 956 & 357 & 93 & 1669 & 371 & 277 & 0.223 \\
Export Category & 956 & 1.884 & 1 & 1.204 & 1.843 & 2.119 & $0.019 * *$ \\
High Irreversibility & 956 & 0.704 & 1 & 0.457 & 0.701 & 0.720 & 0.640 \\
Demand Decrease & 956 & 0.500 & 1 & 0.500 & 0.443 & 0.825 & $0.000 * * *$ \\
Increased Uncertainty & 956 & 0.150 & 0 & 0.357 & 0.000 & 1.000 & \\
\hline
\end{tabular}

Notes: $\mathrm{N}$ denotes the number of observations available for a variable. Mean, Median and St. Dev present statistics that refer to all available observations in the sample. Mean (Certain) and Mean (Uncertain) refers to the mean for the subgroup of uncertain and not uncertain firm. We consider a firm uncertain if the variable "Increased Uncertainty" take value one and certain otherwise. P-Value show the two tail p-value resulting from a comparison of Mean (Certain) and Mean (Uncertain) with a two-sample t-test assuming unequal variance. The stars indicate if the means are significantly different at conventional level: $* * * \mathrm{p}<0.01, * * \mathrm{p}<0.05,{ }^{*} \mathrm{p}<0.1$. 
Table 4: Quantitative Investment Plan Revision

Original

Equipment Construction Equipment Construction

\begin{tabular}{|c|c|c|c|c|}
\hline (Intercept) & $\begin{array}{c}0.05 \\
(0.067)\end{array}$ & $\begin{array}{c}-0.0516 \\
(0.1309)\end{array}$ & $\begin{array}{c}0.015 \\
(0.0701)\end{array}$ & $\begin{array}{c}-0.0407 \\
(0.1358)\end{array}$ \\
\hline Demand decrease & $\begin{array}{c}-0.0222 \\
(0.0205)\end{array}$ & $\begin{array}{c}-0.0457 \\
(0.0418)\end{array}$ & $\begin{array}{l}-0.0225 \\
(0.0205)\end{array}$ & $\begin{array}{c}-0.0454 \\
(0.0419)\end{array}$ \\
\hline Increased uncertainty & $\begin{array}{l}-0.0579^{* *} \\
(0.0295)\end{array}$ & $\begin{array}{l}-0.0345 \\
(0.0606)\end{array}$ & $\begin{array}{c}0.0346 \\
(0.0531)\end{array}$ & $\begin{array}{l}-0.0686 \\
(0.105)\end{array}$ \\
\hline High irreversibility & & & $\begin{array}{c}0.0316 \\
(0.0234)\end{array}$ & $\begin{array}{c}-0.0111 \\
(0.0469)\end{array}$ \\
\hline High irr. * Increased unc. & & & $\begin{array}{l}-0.1302^{* *} \\
(0.0619)\end{array}$ & $\begin{array}{c}0.0485 \\
(0.1217)\end{array}$ \\
\hline Lagged Investment Revision & $\begin{array}{c}0.7694^{* * *} \\
(0.029)\end{array}$ & $\begin{array}{c}0.6097^{* * *} \\
(0.043)\end{array}$ & $\begin{array}{c}0.7700^{* * *} \\
(0.029)\end{array}$ & $\begin{array}{l}0.6109^{* * *} \\
(0.0432)\end{array}$ \\
\hline Employees (FTE, log) & $\begin{array}{c}0.0082 \\
(0.0067)\end{array}$ & $\begin{array}{l}0.0185 \\
(0.014)\end{array}$ & $\begin{array}{c}0.0091 \\
(0.0067)\end{array}$ & $\begin{array}{c}0.0182 \\
(0.0141)\end{array}$ \\
\hline Export (6-33\% of turnover) & $\begin{array}{l}-0.0185 \\
(0.0348)\end{array}$ & $\begin{array}{c}-0.0328 \\
(0.0703)\end{array}$ & $\begin{array}{l}-0.0163 \\
(0.0347)\end{array}$ & $\begin{array}{l}-0.0344 \\
(0.0705)\end{array}$ \\
\hline Export (34-66\% of turnover) & $\begin{array}{c}0.0418 \\
(0.0381)\end{array}$ & $\begin{array}{c}0.0412 \\
(0.0769)\end{array}$ & $\begin{array}{c}0.0427 \\
(0.0381)\end{array}$ & $\begin{array}{c}0.0412 \\
(0.0772)\end{array}$ \\
\hline Export (67-100\% of turnover) & $\begin{array}{c}0.0238 \\
(0.0328) \\
\end{array}$ & $\begin{array}{c}0.022 \\
(0.0719) \\
\end{array}$ & $\begin{array}{c}0.0244 \\
(0.0328) \\
\end{array}$ & $\begin{array}{c}0.0209 \\
(0.0722) \\
\end{array}$ \\
\hline Num. obs. & 887 & 445 & 887 & 445 \\
\hline Controls & Yes & Yes & Yes & Yes \\
\hline Estimator & OLS & OLS & OLS & OLS \\
\hline $\mathrm{R}^{2}$ & 0.5141 & 0.4051 & 0.517 & 0.4054 \\
\hline Adj. $R^{2}$ & 0.4679 & 0.2994 & 0.4697 & 0.296 \\
\hline
\end{tabular}

Including zero investment

Equipment Construction Equipment Construction

\begin{tabular}{|c|c|c|c|}
\hline 0.0406 & -0.0093 & 0.0073 & -0.0161 \\
\hline$(0.0619)$ & $(0.0798)$ & $(0.0646)$ & $(0.0832)$ \\
\hline-0.0139 & $-0.0407^{*}$ & -0.0136 & $-0.0405^{*}$ \\
\hline$(0.0183)$ & $(0.0233)$ & $(0.0182)$ & $(0.0233)$ \\
\hline$-0.0534^{* *}$ & -0.0098 & 0.0326 & -0.027 \\
\hline \multirow[t]{5}{*}{$(0.0265)$} & $(0.034)$ & $(0.0498)$ & $(0.0621)$ \\
\hline & & 0.032 & 0.0108 \\
\hline & & $(0.0212)$ & $(0.0269)$ \\
\hline & & $-0.1182^{* *}$ & 0.0233 \\
\hline & & $(0.0573)$ & $(0.072)$ \\
\hline $0.7736^{* * *}$ & $0.6117^{* * *}$ & $0.7739^{* * *}$ & $0.6121^{* * *}$ \\
\hline$(0.0268)$ & $(0.0276)$ & $(0.0267)$ & $(0.0277)$ \\
\hline $0.0098^{*}$ & 0.0101 & $0.0104^{*}$ & 0.0102 \\
\hline$(0.0058)$ & $(0.0074)$ & $(0.0058)$ & $(0.0074)$ \\
\hline-0.0223 & -0.0394 & -0.021 & -0.0398 \\
\hline$(0.0315)$ & $(0.0391)$ & $(0.0314)$ & $(0.0391)$ \\
\hline 0.0258 & -0.0114 & 0.0262 & -0.0116 \\
\hline$(0.035)$ & $(0.0446)$ & $(0.0349)$ & $(0.0446)$ \\
\hline 0.0034 & -0.0213 & 0.0033 & -0.0225 \\
\hline$(0.0298)$ & $(0.039)$ & $(0.0298)$ & $(0.0391)$ \\
\hline 1020 & 923 & 1020 & 923 \\
\hline Yes & Yes & Yes & Yes \\
\hline OLS & OLS & OLS & OLS \\
\hline 0.5203 & 0.4059 & 0.5228 & 0.4062 \\
\hline 0.4805 & 0.351 & 0.4821 & 0.3498 \\
\hline
\end{tabular}

Notes: Standard errors are in parentheses. $* * * p<0.01,{ }^{*} \mathrm{p} p<0.05,{ }^{*} \mathrm{p}<0.1$. The dependent variable represents firm investment plan revision (difference in log investment plans). Control set entails sector (NUTS 2) and region dummies (NACE 2 Digit). F-Test shows a finite-sample F statistic for carrying out a Wald-test-based comparison between our full model and a linearly restricted model neglecting the uncertainty variables. 
Table 5: Robustness Checks

\begin{tabular}{|c|c|c|c|c|c|c|c|c|}
\hline & Original & $\begin{array}{l}\text { Placebo } \\
\text { Original }\end{array}$ & $\begin{array}{c}\text { Alternative } \\
\text { First } \\
\text { Moment } \\
\end{array}$ & $\begin{array}{c}\text { Share of } \\
\text { Foreign } \\
\text { Employees }\end{array}$ & $\begin{array}{c}\text { Placebo Share } \\
\text { of Foreign } \\
\text { Employees }\end{array}$ & $\begin{array}{l}\text { Autumn } \\
2014\end{array}$ & Winsorising & $\begin{array}{c}\text { without } \\
\text { covariates }\end{array}$ \\
\hline (Intercept) & $\begin{array}{c}0.015 \\
(0.0701)\end{array}$ & $\begin{array}{c}0.0147 \\
(0.0851)\end{array}$ & $\begin{array}{c}0.0027 \\
(0.0717)\end{array}$ & $\begin{array}{l}-0.0013 \\
(0.0769)\end{array}$ & $\begin{array}{c}0.0049 \\
(0.0869)\end{array}$ & $\begin{array}{c}0.042 \\
(0.0705)\end{array}$ & $\begin{array}{c}0.0236 \\
(0.0204)\end{array}$ & $\begin{array}{c}0.0142 \\
(0.0202)\end{array}$ \\
\hline Demand decrease & $\begin{array}{l}-0.0225 \\
(0.0205)\end{array}$ & $\begin{array}{c}0.0159 \\
(0.0249)\end{array}$ & $\begin{array}{l}-0.0328 \\
(0.0343)\end{array}$ & $\begin{array}{l}-0.0263 \\
(0.025)\end{array}$ & $\begin{array}{l}(0.0311) \\
(0.0283)\end{array}$ & $\begin{array}{l}-0.0279 \\
(0.0208)\end{array}$ & $\begin{array}{l}-0.0241 \\
(0.0182)\end{array}$ & $\begin{array}{c}-0.0216 \\
(0.0196)\end{array}$ \\
\hline Increased uncertainty & $\begin{array}{c}0.0346 \\
(0.0531)\end{array}$ & $\begin{array}{l}-0.0819 \\
(0.0644)\end{array}$ & $\begin{array}{c}0.0309 \\
(0.0542)\end{array}$ & & & $\begin{array}{c}0.0083 \\
(0.0512)\end{array}$ & $\begin{array}{c}0.0218 \\
(0.0472)\end{array}$ & $\begin{array}{c}0.0124 \\
(0.0515)\end{array}$ \\
\hline High irreversibility & $\begin{array}{c}0.0316 \\
(0.0234)\end{array}$ & $\begin{array}{c}0.0142 \\
(0.0284)\end{array}$ & $\begin{array}{c}0.037 \\
(0.024)\end{array}$ & $\begin{array}{c}0.045 \\
(0.0275)\end{array}$ & $\begin{array}{c}0.0043 \\
(0.0311)\end{array}$ & $\begin{array}{c}0.0273 \\
(0.0235)\end{array}$ & $\begin{array}{c}0.0202 \\
(0.0208)\end{array}$ & $\begin{array}{c}0.0273 \\
(0.0222)\end{array}$ \\
\hline High irr. * Increased unc. & $\begin{array}{c}-0.1302^{* *} \\
(0.0619)\end{array}$ & $\begin{array}{c}0.0389 \\
(0.0751)\end{array}$ & $\begin{array}{l}-0.1345^{* *} \\
(0.0635)\end{array}$ & & & $\begin{array}{c}-0.0999^{*} \\
(0.060)\end{array}$ & $\begin{array}{c}-0.1004^{*} \\
(0.055)\end{array}$ & $\begin{array}{l}-0.1125^{*} \\
(0.0599)\end{array}$ \\
\hline Lagged Investment Revision & $\begin{array}{c}0.7700^{* * *} \\
(0.029)\end{array}$ & & $\begin{array}{l}0.7628^{* * * *} \\
(0.0299)\end{array}$ & $\begin{array}{l}0.7490^{* * *} \\
(0.0325)\end{array}$ & & $\begin{array}{l}0.5678^{* * * *} \\
(0.0278)\end{array}$ & $\begin{array}{c}0.6957^{* * *} \\
(0.0257)\end{array}$ & $\begin{array}{c}0.7589^{* * *} \\
(0.0273)\end{array}$ \\
\hline High share of for. Employees & & & & $\begin{array}{l}0.1066^{* * *} \\
(0.0513)\end{array}$ & $\begin{array}{l}-0.0817 \\
(0.0579)\end{array}$ & & & \\
\hline High share of for. $*$ Decrease $\mathrm{d}$ & & & & $\begin{array}{l}-0.0711 \\
(0.047)\end{array}$ & $\begin{array}{c}0.0466 \\
(0.0531)\end{array}$ & & & \\
\hline High irr. * High share of for. & & & & $\begin{array}{l}-0.1071^{* *} \\
(0.0523)\end{array}$ & $\begin{array}{c}0.0467 \\
(0.0591)\end{array}$ & & & \\
\hline Employees (FTE, log) & $\begin{array}{c}0.0091 \\
(0.0067)\end{array}$ & $\begin{array}{l}-0.0025 \\
(0.0082)\end{array}$ & $\begin{array}{c}0.0082 \\
(0.0069)\end{array}$ & $\begin{array}{c}0.0062 \\
(0.0073)\end{array}$ & $\begin{array}{l}-0.0036 \\
(0.0082)\end{array}$ & $\begin{array}{l}0.0001 \\
(0.007)\end{array}$ & $\begin{array}{l}0.0085 \\
(0.006)\end{array}$ & \\
\hline Export (6-33\% of turnover) & $\begin{array}{l}-0.0163 \\
(0.0347)\end{array}$ & $\begin{array}{c}0.0646 \\
(0.0421)\end{array}$ & $\begin{array}{l}-0.0219 \\
(0.0356)\end{array}$ & $\begin{array}{l}-0.0126 \\
(0.0367)\end{array}$ & $\begin{array}{c}0.0631 \\
(0.0414)\end{array}$ & $\begin{array}{c}0.0357 \\
(0.0341)\end{array}$ & $\begin{array}{l}-0.0109 \\
(0.0309)\end{array}$ & \\
\hline Export (34-66\% of turnover) & $\begin{array}{c}0.0427 \\
(0.0381)\end{array}$ & $\begin{array}{c}0.0412 \\
(0.0462)\end{array}$ & $\begin{array}{c}0.0374 \\
(0.0389)\end{array}$ & $\begin{array}{c}0.0646 \\
(0.0411)\end{array}$ & $\begin{array}{c}0.0433 \\
(0.0465)\end{array}$ & $\begin{array}{c}0.038 \\
(0.0372)\end{array}$ & $\begin{array}{c}0.0426 \\
(0.0338)\end{array}$ & \\
\hline Export (67-100\% of turnover) & $\begin{array}{c}0.0244 \\
(0.0328) \\
\end{array}$ & $\begin{array}{l}-0.0014 \\
(0.0398) \\
\end{array}$ & $\begin{array}{c}0.0269 \\
(0.0339) \\
\end{array}$ & $\begin{array}{c}0.0272 \\
(0.0357) \\
\end{array}$ & $\begin{array}{c}0.0612 \\
(0.0403) \\
\end{array}$ & $\begin{array}{l}0.0124 \\
(0.033) \\
\end{array}$ & $\begin{array}{c}0.0248 \\
(0.0292) \\
\end{array}$ & \\
\hline Num. obs. & 887 & 887 & 859 & 819 & 819 & 944 & 887 & 887 \\
\hline Controls & Yes & Yes & Yes & Yes & Yes & Yes & Yes & No \\
\hline $\mathrm{R}^{2}$ & 0.517 & 0.1137 & 0.5084 & 0.4765 & 0.1298 & 0.3865 & 0.5294 & 0.4727 \\
\hline Adj. $R^{2}$ & 0.4697 & 0.0281 & 0.4585 & 0.4198 & 0.0367 & 0.3312 & 0.4834 & 0.4697 \\
\hline
\end{tabular}

Notes: Standard errors are in parentheses. $* * * p<0.01, * * p<0.05, * p<0.1$. The model "Original" represents our main specification of Table 4 for investment in equipment and machinery. The model "Placebo Original" regresses our original model against revisions in equipment and machinery for the year 2013. The models "Alternative First moment" and "Share of Foreign Employees" use alternative measures to proxy shifts in the first moment. Whereas the first uses alternative data from a subsequent survey, the second uses the share of foreign employees to measure the exposure of a firm to uncertainty. The variable "High share of foreign Employees" takes the value one for firms with a high share of foreign employees, i.e. if a firm belongs to the upper 25\% regarding the foreign workers share, and zero otherwise. The model "Placebo "Share of Foreign Employees" regresses the model "Share of Foreign Employees" against revisions in equipment and machinery for the year 2013. The model "Autumn 2014" replaces the data levied in spring 2014 with data levied in autumn 2014. The model "Winsorising" truncates $1 \%$ of the most extreme values of the dependent variable, i.e. we set the largest values equal to the value corresponding to the 0.995 quantile and the lowest values to those corresponding to the 0.005 quantile. The model "Interaction Share of Export with Demand" interacts the variable "Demand decrease" with a firms' share of export. The model "without covariates" does not control for firms' share of export, the number of employees and region and sector effects. 
Table 6: Self-Reported Downward Revisions

\begin{tabular}{lcccc}
\hline & 2014 & 2015 & 2016 & 2017 \\
\hline Demand decrease & 0.028 & $0.039 *$ & $0.091 * * *$ & $0.089 * * *$ \\
& $(0.019)$ & $(0.023)$ & $(0.026)$ & $(0.026)$ \\
Increased uncertainty & $0.066^{* * *}$ & $0.170 * * *$ & $0.197 * * *$ & $0.197 * * *$ \\
& $(0.023)$ & $(0.03)$ & $(0.036)$ & $(0.035)$ \\
High irreversibility & -0.025 & -0.027 & 0.02 & 0.019 \\
& $(0.026)$ & $(0.032)$ & $(0.035)$ & $(0.034)$ \\
High irr. * Increased unc. & 0.011 & 0.001 & -0.022 & -0.028 \\
& $(0.028)$ & $(0.039)$ & $(0.044)$ & $(0.043)$ \\
Observations & 779 & 749 & 701 & 680 \\
Controls & Yes & Yes & Yes & Yes \\
pseudo R2 & 0.406 & 0.368 & 0.454 & 0.457 \\
Log Likelihood & -48.63 & -125.8 & -124.3 & -116.4 \\
\hline
\end{tabular}

Notes: Standard errors are in parentheses. $* * * \mathrm{p}<0.01, * * \mathrm{p}<0.05, * \mathrm{p}<0.1$. Logit regressions are carried out and average marginal effects are reported. Control set entails sector, export, size-class and region dummies.

\section{Figures}

Figure 1: Timing of the KOF Investment Surveys Relative to Referendum

\begin{tabular}{|c|c|c|c|c|c|}
\hline 2013 & & 2014 & & & \\
\hline Oct 13 Dec 13 & Apr 14 & Jun 14 & Aug 14 & Oct 14 & Dec 14 \\
\hline$\longmapsto_{\text {Survey Aut13 }}$ & $\stackrel{\longmapsto}{\longmapsto}$ & & & Sur & ey Aut14 \\
\hline
\end{tabular}

Feb 9 
Figure 2: Degree of Irreversibility of Investment ( 1 = full reversibility, 4 = full irreversibility)

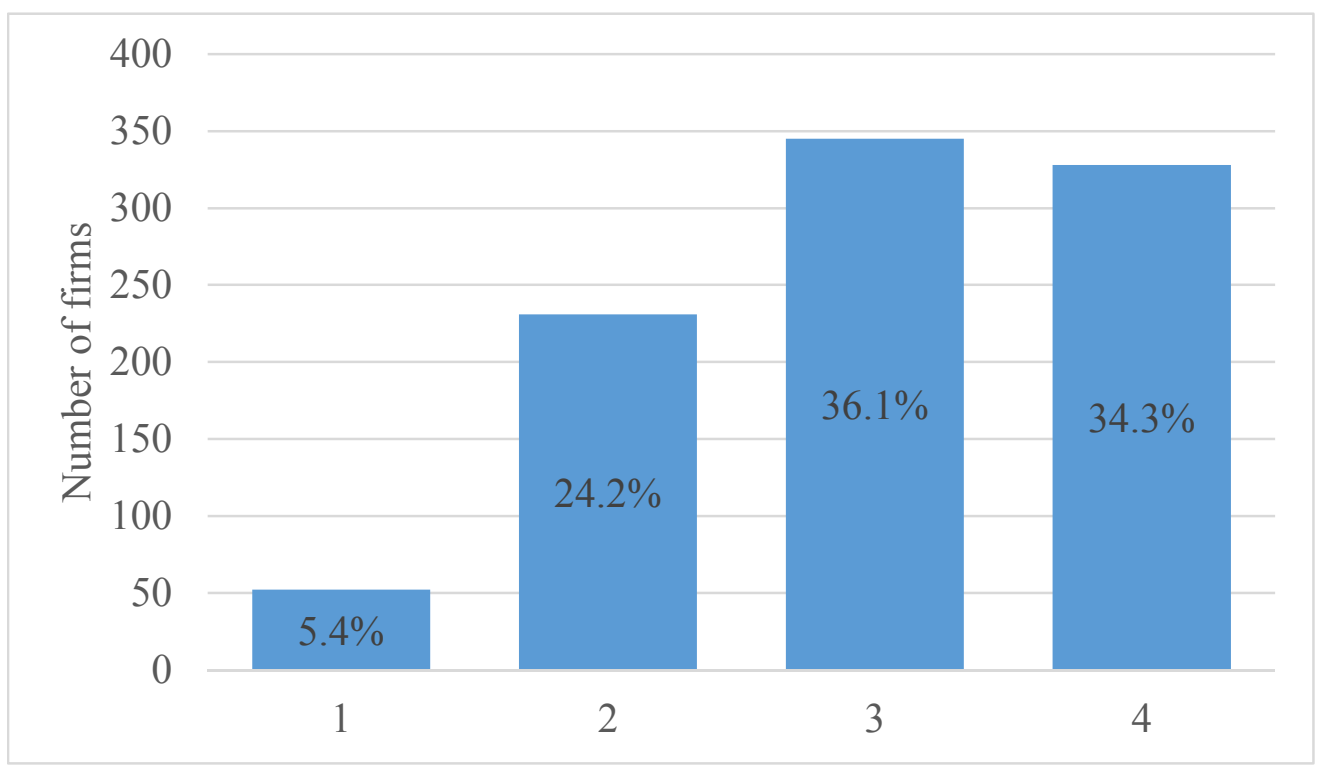

\section{Appendix A: Additional robustness checks}

Table A.1: Adjusting for Unit Non-Response

\begin{tabular}{|c|c|c|c|c|c|c|c|c|c|c|}
\hline \multirow[b]{3}{*}{ (Intercept) } & \multicolumn{4}{|c|}{ Original } & \multicolumn{4}{|c|}{ Non-Response Correction } & \multirow{2}{*}{\multicolumn{2}{|c|}{$\begin{array}{c}\text { First Stage } \\
\text { Non - } \\
\text { Response }\end{array}$}} \\
\hline & Equipment & Construction & Equipment & Construction & Equipment & Construction & Equipment & Construction & & \\
\hline & $\begin{array}{c}0.05 \\
(0.067)\end{array}$ & $\begin{array}{l}-0.0516 \\
(0.1309)\end{array}$ & $\begin{array}{c}0.015 \\
(0.0701)\end{array}$ & $\begin{array}{l}-0.0407 \\
(0.1358)\end{array}$ & $\begin{array}{c}0.0369 \\
(0.0638)\end{array}$ & $\begin{array}{c}-0.024 \\
(0.1266)\end{array}$ & $\begin{array}{c}0.007 \\
(0.0668)\end{array}$ & $\begin{array}{l}-0.0267 \\
(0.1309)\end{array}$ & $\begin{array}{c}-5.5759 \\
(973.4987)\end{array}$ & (Intercept) \\
\hline Demand decrease & $\begin{array}{l}-0.0222 \\
(0.0205)\end{array}$ & $\begin{array}{l}-0.0457 \\
(0.0418)\end{array}$ & $\begin{array}{l}-0.0225 \\
(0.0205)\end{array}$ & $\begin{array}{l}-0.0454 \\
(0.0419)\end{array}$ & $\begin{array}{l}-0.0269 \\
(0.0201)\end{array}$ & $\begin{array}{c}-0.051 \\
(0.0417)\end{array}$ & $\begin{array}{c}-0.027 \\
(0.0201)\end{array}$ & $\begin{array}{l}-0.0512 \\
(0.0419)\end{array}$ & $\begin{array}{c}-4.5203 \\
(686.4091)\end{array}$ & Language English \\
\hline Increased uncertainty & $\begin{array}{l}-0.0579^{* *} \\
(0.0295)\end{array}$ & $\begin{array}{l}-0.0345 \\
(0.0606)\end{array}$ & $\begin{array}{c}0.0346 \\
(0.0531)\end{array}$ & $\begin{array}{l}-0.0686 \\
(0.105)\end{array}$ & $\begin{array}{c}-0.0525^{*} \\
(0.029)\end{array}$ & $\begin{array}{l}-0.0438 \\
(0.0609)\end{array}$ & $\begin{array}{c}0.0291 \\
(0.0514)\end{array}$ & $\begin{array}{l}-0.0446 \\
(0.1047)\end{array}$ & $\begin{array}{c}-0.1348^{* * *} \\
(0.0458)\end{array}$ & Language French \\
\hline High irreversibility & & & $\begin{array}{c}0.0316 \\
(0.0234)\end{array}$ & $\begin{array}{l}-0.0111 \\
(0.0469)\end{array}$ & & & $\begin{array}{c}0.0268 \\
(0.0226)\end{array}$ & $\begin{array}{c}0.0045 \\
(0.0465)\end{array}$ & $\begin{array}{c}0.1238 \\
(0.0802)\end{array}$ & Language Italian \\
\hline High irr. * Increased unc. & & & $\begin{array}{l}-0.1302^{* *} \\
(0.0619)\end{array}$ & $\begin{array}{c}0.0485 \\
(0.1217)\end{array}$ & & & $\begin{array}{l}-0.1165^{*} \\
(0.0603)\end{array}$ & $\begin{array}{c}0.001 \\
(0.1219)\end{array}$ & $\begin{array}{l}-0.2596 \\
(0.203)\end{array}$ & Gender: unknow \\
\hline Lagged Investment Revision & $\begin{array}{c}0.7694^{* * *} \\
(0.029)\end{array}$ & $\begin{array}{c}0.6097^{* * *} \\
(0.043)\end{array}$ & $\begin{array}{l}0.7700^{* * * *} \\
(0.029)\end{array}$ & $\begin{array}{l}0.6109^{* * * *} \\
(0.0432)\end{array}$ & $\begin{array}{c}0.7495^{* * *} \\
(0.028)\end{array}$ & $\begin{array}{l}0.6901^{* * *} \\
(0.0426)\end{array}$ & $\begin{array}{l}0.7502^{* * *} \\
(0.0279)\end{array}$ & $\begin{array}{l}0.6900^{* * *} \\
(0.0427)\end{array}$ & $\begin{array}{c}-0.1591^{* * *} \\
(0.048)\end{array}$ & Gender: female \\
\hline Employees (FTE, log) & $\begin{array}{c}0.0082 \\
(0.0067)\end{array}$ & $\begin{array}{l}0.0185 \\
(0.014)\end{array}$ & $\begin{array}{c}0.0091 \\
(0.0067)\end{array}$ & $\begin{array}{c}0.0182 \\
(0.0141)\end{array}$ & $\begin{array}{l}0.0108^{*} \\
(0.0064)\end{array}$ & $\begin{array}{c}0.0148 \\
(0.0139)\end{array}$ & $\begin{array}{l}0.0115^{*} \\
(0.0065)\end{array}$ & $\begin{array}{c}0.0148 \\
(0.0139)\end{array}$ & $\begin{array}{c}-0.6955^{* * *} \\
(0.0792)\end{array}$ & Gender: not available \\
\hline Export (6-33\% of turnover) & $\begin{array}{l}-0.0185 \\
(0.0348)\end{array}$ & $\begin{array}{l}-0.0328 \\
(0.0703)\end{array}$ & $\begin{array}{l}-0.0163 \\
(0.0347)\end{array}$ & $\begin{array}{l}-0.0344 \\
(0.0705)\end{array}$ & $\begin{array}{l}-0.0265 \\
(0.0344)\end{array}$ & $\begin{array}{l}-0.0088 \\
(0.071)\end{array}$ & $\begin{array}{l}-0.0234 \\
(0.0344)\end{array}$ & $\begin{array}{l}-0.0088 \\
(0.0714)\end{array}$ & $\begin{array}{l}0.7942^{* * *} \\
(0.0365)\end{array}$ & On-line Participant \\
\hline Export (34-66\% of turnover) & $\begin{array}{c}0.0418 \\
(0.0381)\end{array}$ & $\begin{array}{c}0.0412 \\
(0.0769)\end{array}$ & $\begin{array}{c}0.0427 \\
(0.0381)\end{array}$ & $\begin{array}{c}0.0412 \\
(0.0772)\end{array}$ & $\begin{array}{c}0.0326 \\
(0.0382)\end{array}$ & $\begin{array}{c}0.0547 \\
(0.0795)\end{array}$ & $\begin{array}{c}0.0343 \\
(0.0381)\end{array}$ & $\begin{array}{c}0.0552 \\
(0.0799)\end{array}$ & & \\
\hline Export (67-100\% of turnover) & $\begin{array}{c}0.0238 \\
(0.0328) \\
\end{array}$ & $\begin{array}{c}0.022 \\
(0.0719) \\
\end{array}$ & $\begin{array}{c}0.0244 \\
(0.0328) \\
\end{array}$ & $\begin{array}{c}0.0209 \\
(0.0722) \\
\end{array}$ & $\begin{array}{c}0.0333 \\
(0.0324) \\
\end{array}$ & $\begin{array}{c}0.0405 \\
(0.0722) \\
\end{array}$ & $\begin{array}{c}0.0348 \\
(0.0324) \\
\end{array}$ & $\begin{array}{c}0.0405 \\
(0.0724) \\
\end{array}$ & & \\
\hline Num. obs. & 887 & 445 & 887 & 445 & 887 & 445 & 887 & 445 & 8096 & Num. obs. \\
\hline Controls & Yes & Yes & Yes & Yes & Yes & Yes & Yes & Yes & Yes & Controls \\
\hline Estimator & OLS & OLS & OLS & OLS & WLS & WLS & WLS & WLS & Probit & Estimator \\
\hline $\mathrm{R}^{2}$ & 0.5141 & 0.4051 & 0.517 & 0.4054 & 0.5226 & 0.4688 & 0.5203 & 0.4688 & 8391.734 & AIC \\
\hline Adj. $\mathrm{R}^{2}$ & 0.4679 & 0.2994 & 0.4697 & 0.296 & 0.4759 & 0.371 & 0.4746 & 0.3743 & -3688.87 & Log Likelihood \\
\hline
\end{tabular}

Notes: Standard errors are in parentheses. ${ }^{* *} \mathrm{p}<0.01,{ }^{* *} \mathrm{p}<0.05,{ }^{*} \mathrm{p}<0.1$. The model "Original" represents our main specification of Table 4 for investment in equipment and machinery and investment in construction. The model "NonResponse Correction" re-estimates the main specifications using WLS to correct for potential non-response bias. We use inverse probability weighting to weigh single observations. The model "First Stage" explains unit non-response based on firm characteristics by estimating a probit model. The dependent variable takes value one if a firm answered in autumn 2013 and in spring 2014 and zero otherwise. We use firm, respondent and survey design characteristics to explain unit non-response. Particularly, we use the sector a firm operates in (coefficients not show). Furthermore, we use the language that is used to 
address the firms (German, French, Italian or English), the gender of the contact person within the firm (male, female, unknown and not available in case we did not address a person but the firm in general) and the method that a firm uses to participate (paper-based or internet). The correlation between the dependent variable and the fitted values is 0.27 . We use the fitted probabilities of the Probit model to construct firm specific weights.

Table A.2: Including Zero Investment

Original

Equipment Construction Equipment Construction Equipment Construction Equipment Construction

\begin{tabular}{|c|c|c|c|c|c|c|c|c|}
\hline (Intercept) & $\begin{array}{c}0.05 \\
(0.067)\end{array}$ & $\begin{array}{c}-0.0516 \\
(0.1309)\end{array}$ & $\begin{array}{c}0.015 \\
(0.0701)\end{array}$ & $\begin{array}{c}-0.0407 \\
(0.1358)\end{array}$ & $\begin{array}{c}0.0406 \\
(0.0619)\end{array}$ & $\begin{array}{l}-0.0093 \\
(0.0798)\end{array}$ & $\begin{array}{c}0.0073 \\
(0.0646)\end{array}$ & $\begin{array}{c}-0.0161 \\
(0.0832)\end{array}$ \\
\hline Demand decrease & $\begin{array}{l}-0.0222 \\
(0.0205)\end{array}$ & $\begin{array}{l}-0.0457 \\
(0.0418)\end{array}$ & $\begin{array}{l}-0.0225 \\
(0.0205)\end{array}$ & $\begin{array}{l}-0.0454 \\
(0.0419)\end{array}$ & $\begin{array}{l}-0.0139 \\
(0.0183)\end{array}$ & $\begin{array}{l}-0.0407^{*} \\
(0.0233)\end{array}$ & $\begin{array}{l}-0.0136 \\
(0.0182)\end{array}$ & $\begin{array}{l}-0.0405^{*} \\
(0.0233)\end{array}$ \\
\hline Increased uncertainty & $\begin{array}{l}-0.0579^{* *} \\
(0.0295)\end{array}$ & $\begin{array}{l}-0.0345 \\
(0.0606)\end{array}$ & $\begin{array}{c}0.0346 \\
(0.0531)\end{array}$ & $\begin{array}{l}-0.0686 \\
(0.105)\end{array}$ & $\begin{array}{l}-0.0534^{* *} \\
(0.0265)\end{array}$ & $\begin{array}{c}-0.0098 \\
(0.034)\end{array}$ & $\begin{array}{c}0.0326 \\
(0.0498)\end{array}$ & $\begin{array}{c}-0.027 \\
(0.0621)\end{array}$ \\
\hline High irreversibility & & & $\begin{array}{c}0.0316 \\
(0.0234)\end{array}$ & $\begin{array}{c}-0.0111 \\
(0.0469)\end{array}$ & & & $\begin{array}{c}0.032 \\
(0.0212)\end{array}$ & $\begin{array}{c}0.0108 \\
(0.0269)\end{array}$ \\
\hline High irr. $*$ Increased unc. & & & $\begin{array}{l}-0.1302^{* * *} \\
(0.0619)\end{array}$ & $\begin{array}{c}0.0485 \\
(0.1217)\end{array}$ & & & $\begin{array}{l}-0.1182^{* *} \\
(0.0573)\end{array}$ & $\begin{array}{l}0.0233 \\
(0.072)\end{array}$ \\
\hline Lagged Investment Revision & $\begin{array}{c}0.7694^{* * *} \\
(0.029)\end{array}$ & $\begin{array}{c}0.6097^{* * *} \\
(0.043)\end{array}$ & $\begin{array}{c}0.7700^{* * *} \\
(0.029)\end{array}$ & $\begin{array}{l}0.6109^{* * *} \\
(0.0432)\end{array}$ & $\begin{array}{l}0.7736^{* * *} \\
(0.0268)\end{array}$ & $\begin{array}{l}0.6117^{* * *} \\
(0.0276)\end{array}$ & $\begin{array}{l}0.7739^{* * *} \\
(0.0267)\end{array}$ & $\begin{array}{l}0.6121^{* *} \\
(0.0277)\end{array}$ \\
\hline Employees (FTE, log) & $\begin{array}{c}0.0082 \\
(0.0067)\end{array}$ & $\begin{array}{l}0.0185 \\
(0.014)\end{array}$ & $\begin{array}{c}0.0091 \\
(0.0067)\end{array}$ & $\begin{array}{c}0.0182 \\
(0.0141)\end{array}$ & $\begin{array}{c}0.0098^{*} \\
(0.0058)\end{array}$ & $\begin{array}{c}0.0101 \\
(0.0074)\end{array}$ & $\begin{array}{l}0.0104^{*} \\
(0.0058)\end{array}$ & $\begin{array}{c}0.0102 \\
(0.0074)\end{array}$ \\
\hline Export (6-33\% of turnover) & $\begin{array}{c}-0.0185 \\
(0.0348)\end{array}$ & $\begin{array}{c}-0.0328 \\
(0.0703)\end{array}$ & $\begin{array}{c}-0.0163 \\
(0.0347)\end{array}$ & $\begin{array}{c}-0.0344 \\
(0.0705)\end{array}$ & $\begin{array}{c}-0.0223 \\
(0.0315)\end{array}$ & $\begin{array}{l}-0.0394 \\
(0.0391)\end{array}$ & $\begin{array}{c}-0.021 \\
(0.0314)\end{array}$ & $\begin{array}{c}-0.0398 \\
(0.0391)\end{array}$ \\
\hline Export (34-66\% of turnover) & $\begin{array}{c}0.0418 \\
(0.0381)\end{array}$ & $\begin{array}{c}0.0412 \\
(0.0769)\end{array}$ & $\begin{array}{c}0.0427 \\
(0.0381)\end{array}$ & $\begin{array}{c}0.0412 \\
(0.0772)\end{array}$ & $\begin{array}{l}0.0258 \\
(0.035)\end{array}$ & $\begin{array}{l}-0.0114 \\
(0.0446)\end{array}$ & $\begin{array}{c}0.0262 \\
(0.0349)\end{array}$ & $\begin{array}{c}-0.0116 \\
(0.0446)\end{array}$ \\
\hline Export ( $67-100 \%$ of turnover) & $\begin{array}{c}0.0238 \\
(0.0328) \\
\end{array}$ & $\begin{array}{c}0.022 \\
(0.0719) \\
\end{array}$ & $\begin{array}{c}0.0244 \\
(0.0328) \\
\end{array}$ & $\begin{array}{c}0.0209 \\
(0.0722) \\
\end{array}$ & $\begin{array}{c}0.0034 \\
(0.0298) \\
\end{array}$ & $\begin{array}{r}-0.0213 \\
(0.039) \\
\end{array}$ & $\begin{array}{c}0.0033 \\
(0.0298) \\
\end{array}$ & $\begin{array}{l}-0.0225 \\
(0.0391)\end{array}$ \\
\hline Num. obs. & 887 & 445 & 887 & 445 & 1020 & 923 & 1020 & 923 \\
\hline Controls & Yes & Yes & Yes & Yes & Yes & Yes & Yes & Yes \\
\hline Estimator & OLS & OLS & OLS & OLS & OLS & OLS & OLS & OLS \\
\hline $\mathrm{R}^{2}$ & 0.5141 & 0.4051 & 0.517 & 0.4054 & 0.5203 & 0.4059 & 0.5228 & 0.4062 \\
\hline Adj. $\mathrm{R}^{2}$ & 0.4679 & 0.2994 & 0.4697 & 0.296 & 0.4805 & 0.351 & 0.4821 & 0.3498 \\
\hline
\end{tabular}

Notes: Standard errors are in parentheses. ${ }^{* *} \mathrm{p}<0.01,{ }^{*} \mathrm{p}<0.05,{ }^{*} \mathrm{p}<0.1$. The model "Original" represents our main specification of Table 4 for investment in equipment and machinery and investment in construction. The model "Including zero investment" re-estimates the main specifications including all firms reporting zero investment. The design of the questionnaire does not allow the discrimination between a firm reporting zero investment and a firm not answering a specific question at all (item non-response). The reason being that the questionnaire prepopulates the quantitative investment questions with zero (see questionnaire in appendix B). This makes it impossible to distinguish between a participant that did not want to state their investment or a firm that wanted to communicate zero investment when leaving the question blank. Thus, we neglect all firms with zero investment in our main specification. The model "Including zero investment" present estimations results that includes all zero entries. 


\section{Appendix B: KOF Investment Surveys}

Special questionnaire added to the KOF investment survey in spring 2014

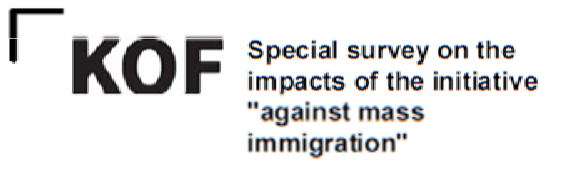
KöF Ŝwiss Ēconomic Institute ETH Zürich, LEE F 124, 8092 Zürich www.kof.ettr.ch

Tel: 0446328533 Fax:044632 1352 "against mass ivu@kof.ethzich

The initiative against mass immigration was accepted on February 9th 2014. As a consequence legislation concerning immigrant regulation has to be renegotiated and adapted within three years. This special survey is designed to collect information on the consequences on investment plans of businesses in Switzerland caused by the

A investments within Ŝwizzeriand

1. How did the acceptance of the initiative against mass immigration influence the certainty of your firm's investment plans within Switzerland in the next three years?

Through the acceptance of the initiative has the certainty of our investment plans within Switzerland in the next three years been

$\begin{array}{rcccc}\begin{array}{l}\text { strongly } \\ \text { decreased }\end{array} & \text { decreased } & \begin{array}{l}\text { not } \\ \text { changed }\end{array} & \text { increased } & \begin{array}{l}\text { strongly } \\ \text { increased }\end{array} \\ \text { more uncertain } & \text { plans } & \text { more certain }\end{array}$

2. Has there been a change in your firm's investment pians (investment sums) within Switzerland due to the acceptance compared to a situation where the initiative would have been rejected, or was there no change?

Due to the acceptance of the initiative, our firm 's investment plans within Switzerland will

\begin{tabular}{|c|c|c|c|c|c|}
\hline & $\begin{array}{l}\text { strongly } \\
\text { decrease }\end{array}$ & decrease & $\begin{array}{l}\text { not } \\
\text { change }\end{array}$ & increase & $\begin{array}{l}\text { strongly } \\
\text { increase }\end{array}$ \\
\hline yea 2014 & 0 & 0 & 0 & 0 & 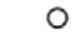 \\
\hline year 2015 & $\mathrm{O}$ & $\mathrm{O}$ & $\mathrm{O}$ & $\mathrm{O}$ & $C$ \\
\hline year 2016 & 0 & 0 & 0 & 0 & $C$ \\
\hline from 2017 & $\mathrm{O}$ & $\mathrm{O}$ & $\mathrm{O}$ & 0 & C \\
\hline
\end{tabular}

B Investments abroad

3. Which of the following statements conceming foreign investments is true for your firm?

a) We are a subsidary of a company and are not $\longrightarrow$ continue with question 5 responsible for foreign

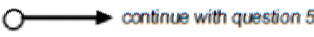
investments

b) Our firm already made yes no foreign investments in $0 \mathrm{O}$ the past (2013 and before)

c) Our firm will undertake $\mathrm{O} \longrightarrow$ continue with question 5 foreign investments in the future (2014 and after)

continue with question 4

4. Has there been a change in your firm's foreign investment plans (investment sums) due to the acceptance compared to a situation where the initiative would have been rejected, or was there no change? acceptance of the initiative. Did the acceptance of the initiative against mass immigration - compared with the situation before or the situation where the initiative would have bee rejected - have an impact on investment plans of your firm, or not?

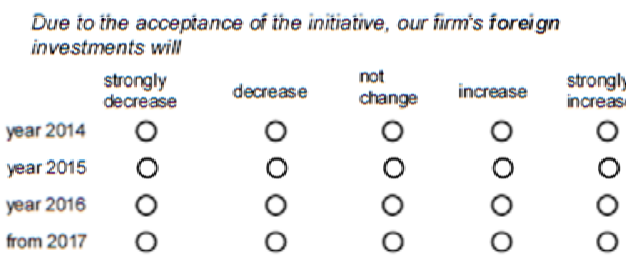

C Personnel plannings

5. Has there been a change in your firm's personnel planning (planned number of overall employees) in Switzerland due to the acceptance compared to a situation where the initiative would have been rejected, or was there no change?

Due to the acceptance of the initiative, our firm's number of employees in Switzerland will

\begin{tabular}{|c|c|c|c|c|c|}
\hline & $\begin{array}{l}\text { strongly } \\
\text { decrease }\end{array}$ & decrease & $\begin{array}{l}\text { not } \\
\text { change }\end{array}$ & increase & $\begin{array}{l}\text { ettrongly } \\
\text { increase }\end{array}$ \\
\hline year 2014 & 0 & 0 & 0 & 0 & 0 \\
\hline year 2015 & 0 & 0 & 0 & 0 & 0 \\
\hline year 2016 & 0 & 0 & 0 & 0 & 0 \\
\hline from 2017 & 0 & 0 & 0 & 0 & 0 \\
\hline
\end{tabular}

6. Wiil there be a change of your firm's recruitment costs due to the acceptance of the initiative or will there be no change?

Due to the acceptance of the initiative, our firm's recruitment costs will

$$
\begin{array}{ccccc}
\begin{array}{c}
\text { strongly } \\
\text { decrease }
\end{array} & \text { decrease } & \begin{array}{c}
\text { not } \\
\text { change }
\end{array} & \text { increase } & \begin{array}{c}
\text { strongly } \\
\text { increase }
\end{array} \\
0 & 0 & 0 & 0 & 0
\end{array}
$$

D General situation

7. It is in our interest to know if in your opinion Swiss medium term growth perspective (overall, not your fim specific) has been influenced be the acceptance of the initiative?

Due to the acceptance of the initiative, growth potential of the Swiss economy will

$$
\begin{array}{ccccc}
\begin{array}{l}
\text { strongly } \\
\text { decrease }
\end{array} & \text { decrease } & \begin{array}{c}
\text { not } \\
\text { change }
\end{array} & \text { increase } & \begin{array}{c}
\text { strongly } \\
\text { increase }
\end{array} \\
\mathrm{O} & \mathrm{O} & \mathrm{O} & \mathrm{O} & \mathrm{O}
\end{array}
$$

E Firm characteristics

The share of foreign employees within Switzerland at the number of all employees within Switzerland is

0
0
0


KOF Swiss Economic Institute ETH Zurich, WEC D 15, 8092 Zürich

Tel. 0446328533 Fax 0446321352 ivu@kof.ethz.ch

\section{Please note}

- Do not use a red pencil.

- Please tick relevant boxes X or enter figures.

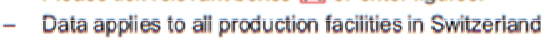

- See explanatory information below.

- Please return the questionnaire by: March 212014

All information will be treated strictly confidentially.

\section{Questions Spring}

\section{Investment activity}

a) Our investments in construction in Switzerland amounted to/is likely to amount to (in CHF 1000)

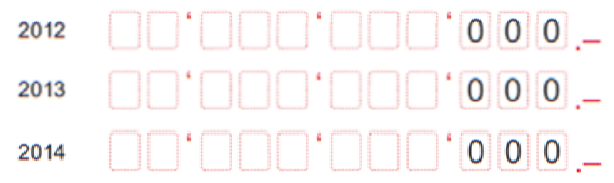

b) Our investments in machinery and equipment and software in Switzerland amounted to/is likely to amount to (in CHF 1000)
2012

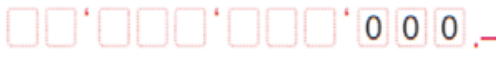
2013
000 .
2014
000 .

c) Relative to 2014 , in the year 2015 our fixed capital formation in Switzerland is likely to

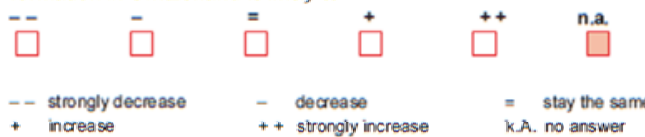

+ increase ++ strongly increase K.A. no answer

2. Number of employees

Number of employees in Ŝwitzerland on December $3 \hat{1}, \hat{2} 0 \hat{1} \hat{3}$ (please convert part-time positions into full-time equivalent positions)

\section{Explanations}

\section{General remarks}

The Investment Survey is an instrument for the early recording of planned investment trends.

\section{Question 1}

The "investment" addressed by this question means inflows minus outflows of fixed capital assets. These should be recorded before depreciation on the basis of their purchase price, i.e. this constitutes gross investment. It is irrelevant whether the equipment which is being used for the first time is new or second-hand, and whether this has been bought, hired or created in-house.

Fixed capital formation consequently encompasses:

\section{Construction}

- New construction, conversion work and renovation of commercial premises. Machinery and equipment

- Machinery, mechanical plants, conveying equipment and warehouse equipment, office machines incl. IT (hardware and software), furniture and equipment, vehides used for business purposes, and (only) such services which are designed to preserve, to improve or to renovate plants
This consequently means that fixed capital formation does not constitute:

- Financial investment (e.g. participations, securities)

- Investment in residential property

- Real estate costs

- Buildings and plants which are intended for hire by the lessor, where the lessor acts merely as a (third-party) financier

- Inventory investment (boosting inventories)

- Intangible assets (e.g. expenditure on marketing concepts; for human capital; for research \& development; for patents and licenœs, excepting for software) 
Investment Cycles Industry / Construction
ǨOF Swiss Economic institute ETH Zurich, WEC D 15, 8092 Zürich www.kof.ethz.ch
Phone 0446322596

Fax 0446321352 ivu@kof.ethz.ch

\section{Please note}

- Do not use a red pencil.

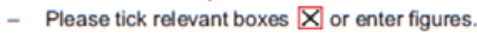

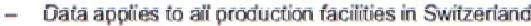

(exception: Question 6).

- See explanatory information on the reverse.

- Please return the questionnaine by: 1 November 2013.

All information will be treated strictly confidentially.

\section{Questions autumn}

Number of employees in Switzeriand on 30 June 2013 (please convert part-time positions into full-time equivalent positions)

in 2013 the following percentage of our production was exported
$\square 0-5 \%$
$\square$ 6-33\%
$\square 34-66 \%$
$\square 67-100 \%$

1. Investment activity

a) Our investments in Construction in Switzerland amounted to/is likely to amount to

(n CHF 1000)

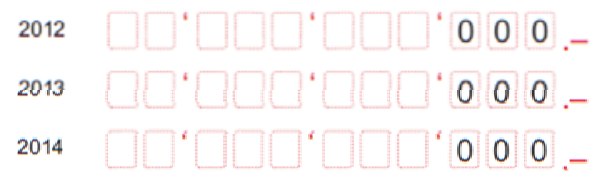

b) Our investments in fixed assets and software in Switzerland amounted to/is likely to amount to (in CHF 1000)

$2012 \square \square \square \square \square \cdot \square \square \square \cdot 000$.-

$2013 \square \square \cdot \square \square \square \cdot \square \square \square \cdot 000$.-

$2014 \square \square \cdot \square \square \square \cdot \square \square \square \cdot 000$.-

c) Relative to 2013 , in the year 2014 our investment

in Switzerland is likely to Machinery
and equipment Construction

increase

remain unchanged

(or remain at zero)

decrease

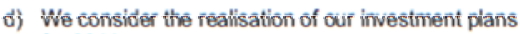
for 2014 as
$\square$ vory
$\square$ fairty

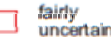
uncertain

2. Structure of the investment

\section{Our investment in 2013/2014 serves}

(you may pick one or more categories)
a) replacement
b) extension of the production capacity
c) to streamline production
d) environmental protection and regulations by trade law

2013

2014

e) other objectives

\section{Product programme}

In terms of our product programme, in the year 2014 we are planning to retain our product range

bring our products into line with the state of the art

add new products to the product range

\section{Production capacity}

In comparison to 2013 , our technical production capacity in Switzerland in the year 2014 shall probably

$\square$ expand

$\square$ leave unchanged

reduce

5. Factors influencing the investment activity

Our investment activity will be positively/negatively influenced in 2013 and 2014 respectively by the following factors:

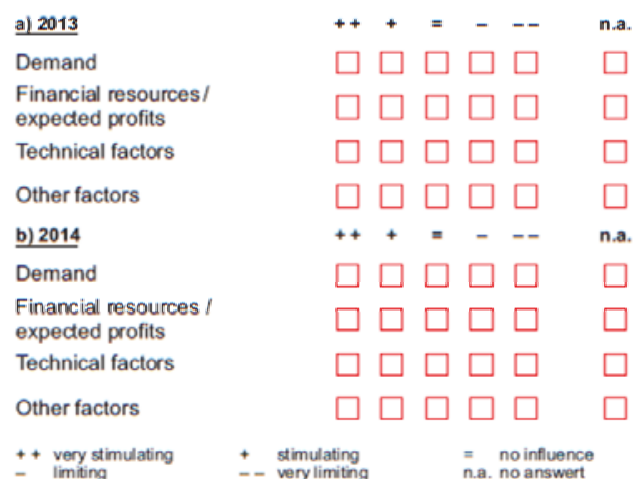

\section{Non-domestic investment}

in the year $20 \hat{0} 14$ we are pianning to make direct investments abroad

$\square$ yes $\quad \square$ no

If yes

The direct investment reiates to the following activities:

Distribution

Production

Research and development 


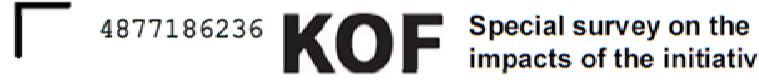 "against mass immigration"}

A Investments within Switzerland

1. How did the acceptance of the initiative against mass immigration influence the certainty of your firm's investment plans within Switzerland in the next three years?

Through the acceptance of the initiative has the certainty of our investment plans within Switzerland in the next three years been

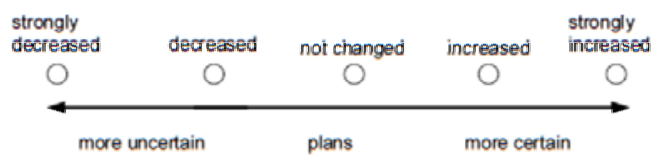

2. Has there been a change in your firm's investment plans (investment sums) within Switzerland due to the acceptance compared to a situation where the initiative would have been rejected, or was there no change?

Due to the acceptance of the initiative, our firm's investment plans within Switzerland will

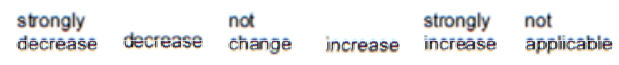

$\begin{array}{lllllll}\text { year 2014 } & 0 & 0 & 0 & 0 & 0 & 0 \\ \text { year 2015 } & 0 & 0 & 0 & 0 & 0 & 0 \\ \text { year 2016 } & 0 & 0 & 0 & 0 & 0 & 0 \\ \text { from 2017 } & 0 & 0 & 0 & 0 & 0 & 0\end{array}$

3. Does your firm underiake $i$ impiement one of the foliowing measurements within 2016 due to the acceptance of the initiative? (please tick all that apply)

Cancei investments

Postpone Investments

Anticipate Investments

Relocate Investments abroad

Implementing streamlining investments $\square$

None of the above applies

\section{Personnel plannings}

4. Has there been a change in your firm's personnel planning (planned number of overall employees) in Switzerland due to the acceptance compared to a situation where the initiative would have been rejected, or was there no change?

Due to the acceptance of the initiative, our firm's number of employees in Switzerland will

$\begin{array}{lcccccc}\text { strongly } & \text { decrease } & \text { decrease } & \begin{array}{c}\text { not } \\ \text { change }\end{array} & \begin{array}{c}\text { strongly } \\ \text { increase } \\ \text { increase }\end{array} & \begin{array}{c}\text { not } \\ \text { applicable }\end{array} \\ \text { year 2014 } & \bigcirc & 0 & 0 & 0 & 0 & 0 \\ \text { year 2015 } & 0 & 0 & 0 & 0 & 0 & 0 \\ \text { year 2016 } 2016 & 0 & 0 & 0 & 0 & 0 & 0 \\ \text { from 2017 } & 0 & 0 & 0 & 0 & 0 & 0\end{array}$

KOF Swiss Economic Institute

TH Zürich, LEE F 105, 8092 Zürich 0446328533

wwwk of ethzch ivu@kof etrech
C Firm's prospects

5. Will there be a change of your firm's recruitment costs due to the acceptance of the initiative or will there be no change?

Due to the acceptance of the initiative, our firm's recruitment costs will

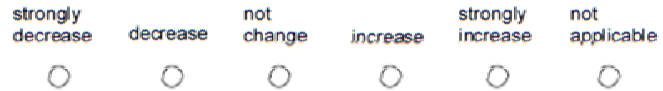

6. The acceptance of the initiative causes our firm's demand potential to

\begin{tabular}{|c|c|c|c|c|c|}
\hline $\begin{array}{l}\text { strongly } \\
\text { dêciêêâsêtê }\end{array}$ & decrease & $\begin{array}{l}\text { not } \\
\text { čnâñ̂nge }\end{array}$ & increase & $\begin{array}{l}\text { strongly } \\
\text { înçuêêașê }\end{array}$ & $\begin{array}{l}\text { not } \\
\text { âpópliçâabiê }\end{array}$ \\
\hline 0 & 0 & 0 & 0 & 0 & c \\
\hline
\end{tabular}

7. How could you assess your firm's current level of competitive intensity in your main market?

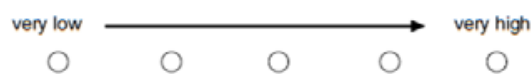

8. Bearing in mind the type of equipment/machinery used in making your main product/services, we would like to know whether a secondhand market exists where in case of need it could be sold.

Yes, and it is relatively easy to find a buyer in a short time willing to pay a reasonable price.

Yes, but it takes time to find a buyer and selling prices are not very rewarding.

Yes, but it is very difficult to find a buyer and selling prices can become very low.

No, there is no such market.

0

E General situation

9. it is in our interest to know if in your opinion Swiss medium term growth perspective (overall, not your firm specific) has been influenced be the acceptance of the initiative?

Due to the acceptance of the initiative, growth potential of the Swiss economy will $\begin{array}{llll}\begin{array}{l}\text { strongly } \\ \text { decrease decrease }\end{array} & \begin{array}{l}\text { not } \\ \text { change increase }\end{array} & \begin{array}{l}\text { strongly } \\ \text { increase }\end{array} & \begin{array}{l}\text { not } \\ \text { applicable }\end{array}\end{array}$

O 0000000

G Firm characteristics

10. The share of foreign employees within Switzerland at the number of all employees within Switzerland is

\begin{tabular}{|c|c|}
\hline & \\
\hline yes & no \\
\hline 0 & 0 \\
\hline yes & no \\
\hline 0 & 0 \\
\hline
\end{tabular}

